Article

\title{
Effect of Transition Metal Substitution on the Charge-Transfer Phase Transition and Ferromagnetism of Dithiooxalato-Bridged Hetero Metal Complexes, $\left(n-\mathrm{C}_{3} \mathrm{H}_{7}\right)_{4} \mathrm{~N}\left[\mathrm{Fe}^{\mathrm{II}}{ }_{1-x} \mathrm{Mn}^{\mathrm{II}}{ }_{x} \mathrm{Fe}^{\mathrm{III}}(\mathrm{dto})_{3}\right]$
}

\author{
Masaya Enomoto ${ }^{1, *}$, Hiromichi Ida ${ }^{1}$, Atsushi Okazawa ${ }^{2}$ (D) and Norimichi Kojima ${ }^{3}$ \\ 1 Department of Chemistry, Faculty of Science Division I, Tokyo University of Science, Tokyo 162-8601, \\ Japan; h.ida1228@gmail.com \\ 2 Department of Basic Science, Graduate School of Arts and Sciences, The University of Tokyo, \\ Tokyo 153-8902, Japan; cokazawa@mail.ecc.u-tokyo.ac.jp \\ 3 Toyota Physical and Chemical Research Institute, Aichi 480-1192, Japan; kojima@toyotariken.jp \\ * Correspondence: menomoto@rs.kagu.tus.ac.jp; Tel.: +81-3-3260-4272 (ext. 5755)
}

Received: 2 October 2018; Accepted: 21 November 2018; Published: 28 November 2018

Abstract: The dithiooxalato-bridged iron mixed-valence complex $\left(n-\mathrm{C}_{3} \mathrm{H}_{7}\right)_{4} \mathrm{~N}\left[\mathrm{Fe}^{\mathrm{II}} \mathrm{Fe}{ }^{\mathrm{III}}(\mathrm{dto})_{3}\right]$ (dto $=$ dithiooxalato) undergoes a novel charge-transfer phase transition (CTPT) accompanied by electron transfer between adjacent $\mathrm{Fe}^{\mathrm{II}}$ and $\mathrm{Fe}^{\mathrm{III}}$ sites. The CTPT influences the ferromagnetic transition temperature according to the change of spin configuration on the iron sites. To reveal the mechanism of the CTPT, we have synthesized the series of metal-substituted complexes $\left(n-\mathrm{C}_{3} \mathrm{H}_{7}\right)_{4} \mathrm{~N}\left[\mathrm{Fe}^{\mathrm{II}}{ }_{1-x} \mathrm{Mn}^{\mathrm{II}}{ }_{x} \mathrm{Fe}^{\mathrm{III}}(\mathrm{dto})_{3}\right](x=0-1)$ and investigated their physical properties by means of magnetic susceptibility and dielectric constant measurements. With increasing $\mathrm{Mn}^{\mathrm{II}}$ concentration, $x$, $\mathrm{Mn}^{\mathrm{II}}$-substituted complexes show the disappearance of CTPT above $x=0.04$, while the ferromagnetic phase remains in the whole range of $x$. These results are quite different from the physical properties of the $\mathrm{Zn}^{\mathrm{II}}$-substituted complex, $\left(n-\mathrm{C}_{3} \mathrm{H}_{7}\right)_{4} \mathrm{~N}\left[\mathrm{Fe}^{\mathrm{II}}{ }_{1-x} \mathrm{Zn}^{\mathrm{II}}{ }_{x} \mathrm{Fe}^{\mathrm{III}}(\mathrm{dto})_{3}\right]$, which is attributed to the difference of ion radius as well as the spin states of $\mathrm{Mn}^{\mathrm{II}}$ and $\mathrm{Zn}^{\mathrm{II}}$.

Keywords: charge-transfer phase transition; iron mixed-valence complex; hetero metal complex; dithiooxalato ligand; substitution of $3 \mathrm{~d}$ transition metal ion; ferromagnetism; dielectric response; ${ }^{57} \mathrm{Fe}$ Mössbauer spectroscopy

\section{Introduction}

Oxalate dianion (ox) is one of the most efficient building components in molecule-based magnets. Owing to its versatile bridging modes [1-10] as well as its remarkable ability to mediate a strong magnetic interaction between paramagnetic metal ions [11], a large number of ox-based coordination compounds with wide ranges of structures and magnetic properties have been reported $[12,13]$. Among these compounds, ox-bridged bimetallic complexes $\left[\mathrm{M}^{\mathrm{II}} \mathrm{M}^{\mathrm{III}}(\mathrm{ox})_{3}\right]^{-}$have been a fascinating target for materials chemistry since the discovery of ferromagnetism in the layered complexes $\left(n-\mathrm{C}_{4} \mathrm{H}_{9}\right)_{4} \mathrm{~N}\left[\mathrm{M}^{\mathrm{II}} \mathrm{Cr}{ }^{\mathrm{III}}(\mathrm{ox})_{3}\right](\mathrm{M}=\mathrm{Cr}, \mathrm{Mn}, \mathrm{Fe}, \mathrm{Co}, \mathrm{Ni}, \mathrm{Cu})$ [14]. These complexes are composed of a molecular building block of trioxalato-coordinated metal anion, $\left[\mathrm{M}^{\mathrm{III}}(\mathrm{ox})_{3}\right]^{3-}$, and a divalent transition metal ion, exhibiting a two-dimensional (2D) sheet or 3D network structure depending on the size, charge and geometry of the counter cation which acts as a template of the formation of the anionic network [13]. In particular, 2D layered complexes accommodate various functional cations as a cation template, obtaining additional functions such as molecular magnetism [15-17], 
spin-crossover [18-21], photochromism [22], electrical or proton conduction [23-28], dielectricity [29], and nonlinear optics [30-32] to cooperate with the magnetism of the ox-bridged bimetallic layer.

In the ox-bridged bimetallic network, the ox can be replaced by its bis-sulfur analogue, 1,2-dithiooxalate (dto), and dto-bridged anionic layered complexes $\left[\mathrm{M}^{\mathrm{II}} \mathrm{M}^{\mathrm{III}}(\mathrm{dto})_{3}\right]^{-}$have actually been developed [33,34]. In this family, the iron mixed-valence complex $\left(n-\mathrm{C}_{3} \mathrm{H}_{7}\right)_{4} \mathrm{~N}\left[\mathrm{Fe}^{\mathrm{II}} \mathrm{Fe} e^{\mathrm{III}}(\mathrm{dto})_{3}\right]$ indicates a reversible charge-transfer phase transition (CTPT) with thermal hysteresis at around $120 \mathrm{~K}$, which is induced by electron transfer between adjacent $\mathrm{Fe}^{\mathrm{II}}$ and $\mathrm{Fe}^{\mathrm{III}}$ sites as shown in Figure 1 [35-37].

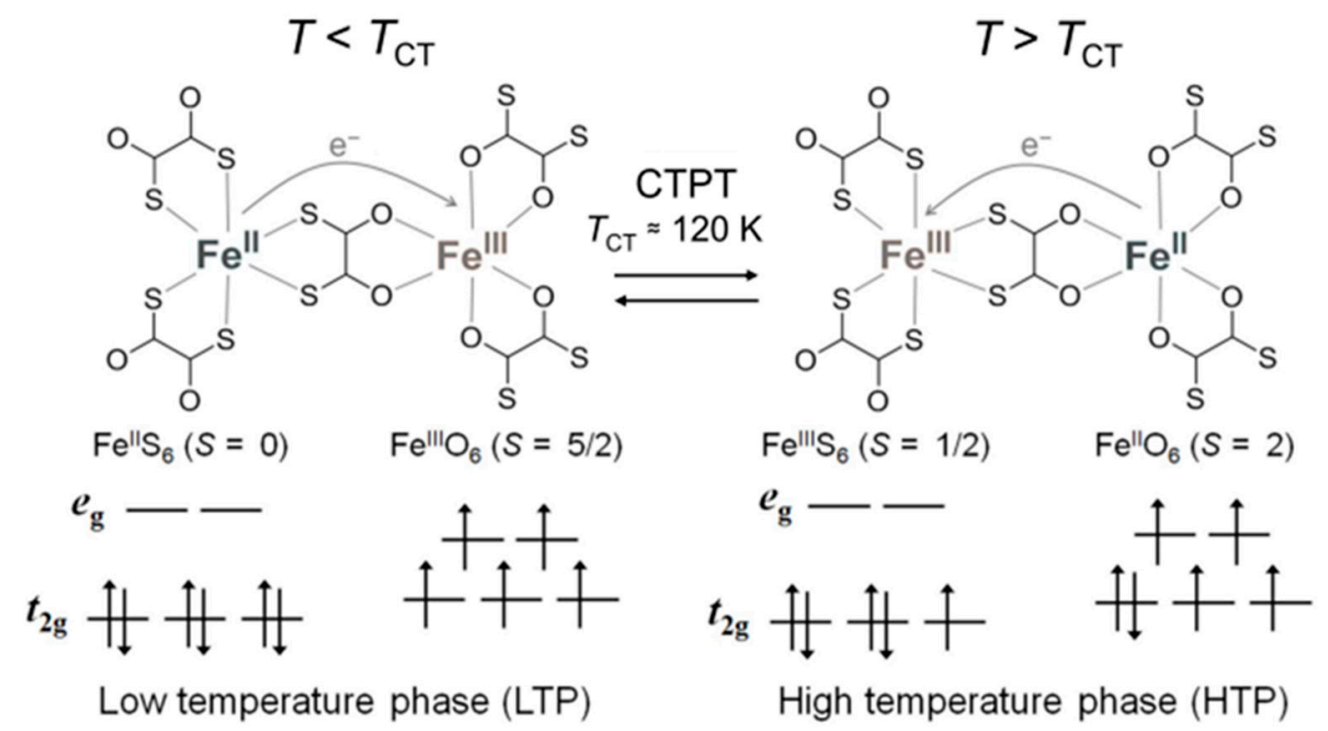

Figure 1. Schematic representation of the charge-transfer phase transition (CTPT) in $\left(n-\mathrm{C}_{3} \mathrm{H}_{7}\right)_{4} \mathrm{~N}\left[\mathrm{Fe}^{\mathrm{II}} \mathrm{Fe}^{\mathrm{III}}(\text { dto })_{3}\right]$.

In the high-temperature phase (HTP; $T>120 \mathrm{~K}), \mathrm{Fe}^{\mathrm{III}}$ with a low-spin state $(S=1 / 2)$ is coordinated by six $\mathrm{S}$ atoms, while $\mathrm{Fe}^{\mathrm{II}}$ with a high-spin state $(S=2)$ is coordinated by six $\mathrm{O}$ atoms. On the other hand, in the low-temperature phase (LTP; $T<120 \mathrm{~K}$ ), the $\mathrm{FeO}_{6}$ and $\mathrm{FeS}_{6}$ sites change to high-spin $\mathrm{Fe}^{\mathrm{III}}(S=5 / 2)$ and diamagnetic low-spin $\mathrm{Fe}^{\mathrm{II}}(S=0)$ species, respectively, according to the charge transfer. $\left(n-\mathrm{C}_{4} \mathrm{H}_{9}\right)_{4} \mathrm{~N}\left[\mathrm{Fe}^{\mathrm{II}} \mathrm{Fe}^{\mathrm{III}}(\mathrm{dto})_{3}\right]$ also exhibits an incomplete CTPT at around $140 \mathrm{~K}$, which results in the coexistence of the HTP and LTP below the CTPT temperature. Contrary to this, $\left(n-\mathrm{C}_{\mathrm{n}} \mathrm{H}_{2 \mathrm{n}+1}\right)_{4} \mathrm{~N}\left[\mathrm{Fe}^{\mathrm{II}} \mathrm{Fe}^{\mathrm{III}}(\mathrm{dto})_{3}\right]$ with $\mathrm{n}=5$ and 6 do not show the CTPT at ambient pressure, and remain in the spin state corresponding to an HTP down to $2 \mathrm{~K}$ [38].

The occurrence or absence of the CTPT in $\left(n-\mathrm{C}_{n} \mathrm{H}_{2 n+1}\right)_{4} \mathrm{~N}\left[\mathrm{Fe}^{\mathrm{II}} \mathrm{Fe}^{\mathrm{III}}(\mathrm{dto})_{3}\right](\mathrm{n}=3-6)$ affects the ferromagnetic transition temperature $\left(T_{C}\right)$, which strongly correlates with the cation size $[38,39]$. The ferromagnetic transition for $\left(n-\mathrm{C}_{3} \mathrm{H}_{7}\right)_{4} \mathrm{~N}\left[\mathrm{Fe}^{\mathrm{II}} \mathrm{Fe}^{\mathrm{III}}(\mathrm{dto})_{3}\right]$ occurs at $7 \mathrm{~K}$ in the LTP, where the spin state of the $\mathrm{Fe}^{\mathrm{II}}$ ion is diamagnetic. For $\left(n-\mathrm{C}_{\mathrm{n}} \mathrm{H}_{2 \mathrm{n}+1}\right)_{4} \mathrm{~N}\left[\mathrm{Fe}^{\mathrm{II}} \mathrm{Fe}^{\mathrm{III}}(\mathrm{dto})_{3}\right](\mathrm{n}=5-6)$, the ferromagnetically coupled $\mathrm{Fe}^{\mathrm{II}}(S=2)$ and $\mathrm{Fe}^{\mathrm{III}}(S=1 / 2)$ ions contribute a higher $T_{\mathrm{C}}$ of $\sim 20 \mathrm{~K}$, which is thanks to the absence of the CTPT. Furthermore, the coexistence of the LTP and HTP in $\left(n-\mathrm{C}_{4} \mathrm{H}_{9}\right)_{4} \mathrm{~N}\left[\mathrm{Fe}^{\mathrm{II}} \mathrm{Fe}^{\mathrm{III}}(\mathrm{dto})_{3}\right]$ affords respective magnetic ordering at $7 \mathrm{~K}$ and $13 \mathrm{~K}$. Thus, the CTPT is a quite important ingredient for the comprehension of magnetic behavior based on the spin states of the metal ions.

Recently, we investigated the magnetic dilution effect on the ferromagnetic transition and the CTPT behavior of $\left(n-\mathrm{C}_{3} \mathrm{H}_{7}\right)_{4} \mathrm{~N}\left[\mathrm{Fe}^{\mathrm{II}} \mathrm{Fe}{ }^{\mathrm{III}}(\mathrm{dto})_{3}\right]$ with the employment of the magnetic diluted system, $\left(n-\mathrm{C}_{3} \mathrm{H}_{7}\right)_{4} \mathrm{~N}\left[\mathrm{Fe}^{\mathrm{II}}{ }_{1-x} \mathrm{Zn}^{\mathrm{II}}{ }_{x} \mathrm{Fe}^{\mathrm{III}}(\mathrm{dto})_{3}\right](x=0-1)[40,41]$. Judging from the results of magnetic susceptibility and dielectric constant measurements, the CTPT is rapidly suppressed by the substitution of a diamagnetic $\mathrm{Zn}^{\mathrm{II}}$ for the $\mathrm{Fe}^{\mathrm{II}}$ ions in the low substituted ratio $x$, and it is absent in $x>0.13$. Such a low critical $\mathrm{Zn}^{\mathrm{II}}$-substituted ratio arises from the high cooperativity of the electron transfer in the CTPT. As a result of the suppression of the CTPT, the $T_{C}$ was enhanced with the substituted ratio $x$ increased from 0.00 to 0.05 . With further increasing of $x, T_{\mathrm{C}}$ monotonically decreases and disappears above $x=$ 
0.96. The introduction of nonmagnetic $\mathrm{Zn}{ }^{\mathrm{II}}$ ions into the $\mathrm{Fe}^{\mathrm{II}}$ sites of the $\left[\mathrm{Fe}^{\mathrm{II}} \mathrm{Fe}^{\mathrm{III}}(\mathrm{dto})_{3}\right]^{-}$layer causes the disconnection of the ferromagnetic exchange pathway, which causes the decrement of $T_{\mathrm{C}}$.

Thus, nonmagnetic dilution in $\left(n-\mathrm{C}_{3} \mathrm{H}_{7}\right)_{4} \mathrm{~N}\left[\mathrm{Fe}^{\mathrm{II}} \mathrm{Fe}^{\mathrm{III}}(\mathrm{dto})_{3}\right]$ simultaneously induces both a disconnection of the ferromagnetic exchange pathway and the suppression of the CTPT; therefore, a further experiment should be performed to elucidate metal-ion substitution effects on magnetic properties in $\left(n-\mathrm{C}_{3} \mathrm{H}_{7}\right)_{4} \mathrm{~N}\left[\mathrm{Fe}^{\mathrm{II}} \mathrm{Fe}^{\mathrm{III}}(\mathrm{dto})_{3}\right]$. Substitution with a paramagnetic metal ion is expected to suppress the CTPT without the disconnection of the ferromagnetic exchange pathway. From this viewpoint, we have synthesized new $\mathrm{Mn}^{\mathrm{II}}$-substituted complexes $\left(n-\mathrm{C}_{3} \mathrm{H}_{7}\right)_{4} \mathrm{~N}\left[\mathrm{Fe}^{\mathrm{II}}{ }_{1-x} \mathrm{Mn}^{\mathrm{II}}{ }_{x} \mathrm{Fe}^{\mathrm{III}}(\mathrm{dto})_{3}\right]$ to investigate the effect of magnetic-ion substitution on the CTPT and the magnetic properties of $\left(n-\mathrm{C}_{3} \mathrm{H}_{7}\right)_{4} \mathrm{~N}\left[\mathrm{Fe}^{\mathrm{II}} \mathrm{Fe}^{\mathrm{III}}(\mathrm{dto})_{3}\right]$ by means of magnetic and dielectric constant measurements. Furthermore, a magnetic phase diagram of this system is discussed.

\section{Materials and Methods}

\subsection{Sample Preparation}

Potassium dithiooxalate, $\mathrm{K}_{2}(\mathrm{dto})$, was prepared according to reference [42,43]. The precursor $\mathrm{KBa}\left[\mathrm{Fe}(\mathrm{dto})_{3}\right] \cdot 3 \mathrm{H}_{2} \mathrm{O}$ was also obtained in accordance with the literature [44]. Commercially available reagents and solvents were used without further purification for raw materials.

$\left(n-\mathrm{C}_{3} \mathrm{H}_{7}\right)_{4} \mathrm{~N}\left[\mathrm{Fe}^{\mathrm{II}}{ }_{1-x} \mathrm{Mn}^{\mathrm{II}}{ }_{x} \mathrm{Fe}^{\mathrm{III}}(\mathrm{dto})_{3}\right]$ were prepared by a similar way to the previously reported method [40,41], except for $\mathrm{MnCl}_{2} \cdot 4 \mathrm{H}_{2} \mathrm{O}$ (KANTO CHAMICAL CO., INC., Tokyo, Japan) being used instead of $\mathrm{ZnCl}_{2}$ (KANTO CHAMICAL CO., INC., Tokyo, Japan). The appropriate amount ( $x$ equivalent to the $\mathrm{Fe}{ }^{\mathrm{III}}$ source) of $\mathrm{MnCl}_{2} \cdot 4 \mathrm{H}_{2} \mathrm{O}$ was used according to a reduced amount of $\mathrm{FeCl}_{2} \cdot 4 \mathrm{H}_{2} \mathrm{O}$ (KANTO CHAMICAL CO., INC., Tokyo, Japan) (see Table 1 in the Section 3.1.1).

\subsection{Characterization}

Since the molar fractions of raw materials in the reaction mixture were not directly reflected in the substituted ratio of $\mathrm{Mn}^{\mathrm{II}}$ for $\left(n-\mathrm{C}_{3} \mathrm{H}_{7}\right)_{4} \mathrm{~N}\left[\mathrm{Fe}^{\mathrm{II}}{ }_{1-x} \mathrm{Mn}^{\mathrm{II}}{ }_{x} \mathrm{Fe}^{\mathrm{III}}(\mathrm{dto})_{3}\right]$, the composition of transition-metal ions in $\left(n-\mathrm{C}_{3} \mathrm{H}_{7}\right)_{4} \mathrm{~N}\left[\mathrm{Fe}^{\mathrm{II}}{ }_{1-x} \mathrm{Mn}^{\mathrm{II}}{ }_{x} \mathrm{Fe}^{\mathrm{III}}(\mathrm{dto})_{3}\right]$ was determined by energy-dispersive $\mathrm{X}$-ray spectroscopy (EDS; JEOL, EX-37001) in a field-emission scanning electron microscope (SEM; JEOL, JSM-7001F/SHL).

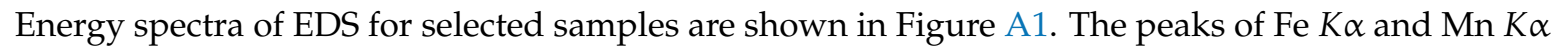
were used for the determination of the substituted ratio.

The powder X-ray diffraction pattern of all these complexes was measured by Rigaku, RINT2500 using $\mathrm{Cu} \mathrm{K} \alpha$ radiation at room temperature.

\subsection{Measurements of Physical Properties}

The static magnetic susceptibility was measured by a superconducting quantum interference device (SQUID) susceptometer (Quantum Design Japan, Tokyo, Japan, MPMS-5 or MPMS-XL7AC). The measuring temperature range and static field were set to $2-300 \mathrm{~K}$ and 5000 Oe, respectively. The diamagnetic contributions were corrected by the application of Pascal's law. The magnetic moment and the magnetic interaction were estimated by fitting the temperature dependence of the magnetic susceptibility in a high temperature region with the Curie-Weiss law, $\chi=C /(T-\theta)$. $C$ and $\theta$ denote the Curie constant and the Weiss temperature, respectively. The temperature dependence of the zero-field-cooled magnetization (ZFCM) and the field-cooled magnetization (FCM) were measured in the temperature range of $2-30 \mathrm{~K}$ under 30 Oe. The remnant magnetization (RM) was measured in the same temperature range under a zero field. The ac magnetic susceptibility measurements were performed in the temperature range of $2-40 \mathrm{~K}$ under an ac magnetic field of 3 Oe and frequency range of $10-1000 \mathrm{~Hz}$.

The temperature dependence of dielectric constants was measured by an impedance gain phase analyzer (AMETEK Japan, Tokyo, Japan, Solartron 1260 equipped with a Solartron 1269). The sample 
was shaped as a pellet and contacted by thin gold wire using the two-probe method. The temperature and the frequency range were selected as $4-300 \mathrm{~K}$ and $1 \mathrm{~Hz}$ to $1 \mathrm{MHz}$, respectively.

\section{Results}

\subsection{Characterization}

\subsubsection{The Composition of Metallic Ions}

The actual ratio of metallic ions was determined by EDS. Table 1 shows the preparation ratio of raw materials and the resultant substitution ratio of $x$ for $\left(n-\mathrm{C}_{3} \mathrm{H}_{7}\right)_{4} \mathrm{~N}\left[\mathrm{Fe}^{\mathrm{II}}{ }_{1-x} \mathrm{Mn}^{\mathrm{II}}{ }_{x} \mathrm{Fe}^{\mathrm{III}}(\mathrm{dto})_{3}\right]$. We often found a difference of the molar fractions between the reaction mixtures and resulting powdered samples. The $\mathrm{Mn}^{\mathrm{II}}$-substitution ratios tend to become lower than the expected value of the corresponding prepared starting materials. The result indicates that the $\mathrm{Mn}^{\mathrm{II}}$ ion is not efficiently incorporated into the dto layer compared with the $\mathrm{Fe}^{\mathrm{II}}$ ion, while the $\mathrm{Zn}^{\mathrm{II}}$-ion uptake into the layer is significantly preferred to the $\mathrm{Fe}^{\mathrm{II}}$ ion $[40,41]$. Such a $\mathrm{M}^{\mathrm{II}}$-substitution tendency reflects the Irving-Williams order $\left(\mathrm{Mn}^{\mathrm{II}}<\mathrm{Fe}^{\mathrm{II}}<\mathrm{Zn}^{\mathrm{II}}\right)$ of the stability for the ox ligand $[45,46]$.

Table 1. The relation between the molar fraction of raw materials in the reaction mixture and resulting values of $x$ for $\left(n-\mathrm{C}_{3} \mathrm{H}_{7}\right)_{4} \mathrm{~N}\left[\mathrm{Fe}^{\mathrm{II}}{ }_{1-x} \mathrm{Mn}^{\mathrm{II}}{ }_{x} \mathrm{Fe}^{\mathrm{III}}(\mathrm{dto})_{3}\right]$ determined by EDS. EDS: energy-dispersive $\mathrm{X}$-ray spectroscopy.

\begin{tabular}{ccccccccc}
\hline Ratio of raw materials & 0.00 & 0.01 & 0.07 & 0.05 & 0.28 & 0.50 & 0.80 & 1.00 \\
Resulting values of $x$ & 0.00 & 0.01 & 0.02 & 0.04 & 0.09 & 0.31 & 0.77 & 1.00 \\
\hline
\end{tabular}

\subsubsection{Powder X-Ray Analysis}

Figure 2 shows the powder $\mathrm{X}$-ray diffraction patterns of $\left(n-\mathrm{C}_{3} \mathrm{H}_{7}\right)_{4} \mathrm{~N}\left[\mathrm{Fe}^{\mathrm{II}}{ }_{1-x} \mathrm{Mn}^{\mathrm{II}}{ }_{x} \mathrm{Fe}^{\mathrm{III}}(\mathrm{dto})_{3}\right]$.

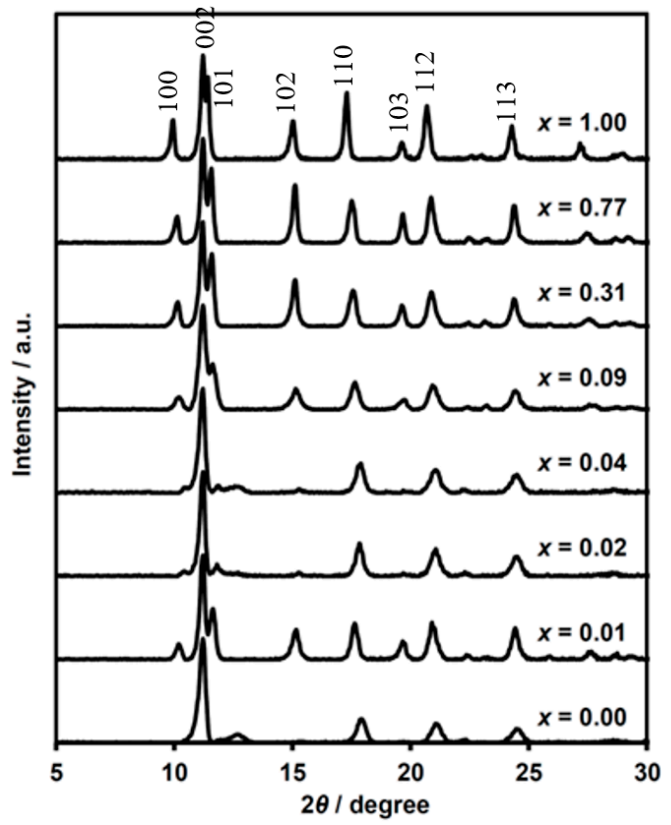

Figure 2. Powder X-ray diffraction patterns of $\left(n-\mathrm{C}_{3} \mathrm{H}_{7}\right)_{4} \mathrm{~N}\left[\mathrm{Fe}^{\mathrm{II}}{ }_{1-x} \mathrm{Mn}_{x}{ }_{x} \mathrm{Fe}^{\mathrm{III}}(\text { dto })_{3}\right]$ at $300 \mathrm{~K}$.

The numbers $h k l$ in Figure 2 indicate the indices of Bragg reflections, which are based on the single crystal X-ray diffraction analysis of $\left(n-\mathrm{C}_{3} \mathrm{H}_{7}\right)_{4} \mathrm{~N}\left[\mathrm{Fe}^{\mathrm{II}} \mathrm{Fe}^{\mathrm{III}}(\mathrm{dto})_{3}\right.$ ] [37]. Judging from the crystal structure of the parent $\left(n-\mathrm{C}_{3} \mathrm{H}_{7}\right)_{4} \mathrm{~N}\left[\mathrm{Fe}^{\mathrm{II}} \mathrm{Fe} \mathrm{III}^{\mathrm{II}}(\mathrm{dto})_{3}\right]$ in the $P 6_{3}$ space group [38], the maximum peaks at around $2 \theta$ of $11^{\circ}$ for all complexes can be assigned to the 002 reflection from interlayer stacking of $\left[\mathrm{Fe}^{\mathrm{II}}{ }_{1-x} \mathrm{Mn}_{x}{ }_{x} \mathrm{Fe}^{\mathrm{III}}(\mathrm{dto})_{3}\right]^{-}$honeycomb sheet along the $c$-axis. The $2 \theta$ value of this reflection is almost 
independent of the substituted ratio $x$, indicating that the layer distance is regulated by the size of the intercalated cation. The smallest $2 \theta$ peaks around $10^{\circ}$ are derived from the 100 reflection correlated with the lattice length along the intralayer direction. The peaks apparently shifted to a lower angle with the increasing of $x$. This finding indicates the elongation of the unit cell length of $a(=b)$, which is reasonable considering the order of metal-ion radii $\left(\mathrm{Mn}^{\mathrm{II}}>\mathrm{Fe}^{\mathrm{II}}\right)$. Similarly, the 110 peak reflected in the intralayer direction shows a tendency to shift toward a lower angle with the increasing of $x$.

The reflections of $10 l$ are quite weak in some complexes, while the $11 l$ reflections remain intense for all measuring complexes. In layered structures, the existence of stacking faults should often be taken into consideration, because the interlayer interaction is weak in general. The difference between hexagonal and cubic close packing is the simple example of periodicity along the stacking layers. In fact, ox-bridged hetero metal complexes show mixed structures between the space groups of $P 6_{3}$ and $R 3 c$ [47-51]. Indeed, $\left(n-\mathrm{C}_{3} \mathrm{H}_{7}\right)_{4} \mathrm{~N}\left[\mathrm{Mn}^{\mathrm{II}} \mathrm{Fe}{ }^{\mathrm{III}}(\mathrm{ox})_{3}\right]$ was determined as a biphasic structure of $\mathrm{P}_{3}$ and $R 3 c$ with a $20-30 \%$ faulting probability of layer stacking, judging from the simulation of the powder $X$-ray diffraction pattern [52]. A high faulting probability in complexes causes the broadening of some diffraction peaks (e.g., $11 l$ indices) related with stacking vectors along the $a+b$ direction.

It should be mentioned that the magnetic properties of the $\left[\mathrm{Fe}^{\mathrm{II}}{ }_{1-x} \mathrm{Mn}^{\mathrm{II}}{ }_{x} \mathrm{Fe}^{\mathrm{III}}(\mathrm{dto})_{3}\right]^{-}$layer systematically depend on the change of the substituted ratio $x$ (see below) although the stacking manner is different among the series of $\left(n-\mathrm{C}_{3} \mathrm{H}_{7}\right)_{4} \mathrm{~N}\left[\mathrm{Fe}^{\mathrm{II}}{ }_{1-x} \mathrm{Mn}^{\mathrm{II}}{ }_{x} \mathrm{Fe}^{\mathrm{III}}(\mathrm{dto})_{3}\right]$.

\subsection{Physical Properties for $\left(n-\mathrm{C}_{3} \mathrm{H}_{7}\right)_{4} \mathrm{~N}\left[\mathrm{Fe}^{I I}{ }_{1-x} \mathrm{Mn}^{I I}{ }_{x} \mathrm{Fe} \mathrm{III}^{\left.I I t o)_{3}\right]}\right.$}

\subsubsection{Magnetism of $\left(n-\mathrm{C}_{3} \mathrm{H}_{7}\right)_{4} \mathrm{~N}\left[\mathrm{Fe}^{\mathrm{II}} \mathrm{Fe}^{\mathrm{III}}(\mathrm{dto})_{3}\right]$ and a Series of Nonmagnetic Substituted Complexes}

In the case of $\left(n-\mathrm{C}_{3} \mathrm{H}_{7}\right)_{4} \mathrm{~N}\left[\mathrm{Fe}^{\mathrm{II}} \mathrm{Fe}^{\mathrm{III}}(\mathrm{dto})_{3}\right]$, the characteristic behavior of CTPT in magnetic susceptibility shows the existence of a thermal hysteresis loop, which is induced by the cooperative effect of electron transfer between $\mathrm{Fe}^{\mathrm{II}}-\mathrm{Fe}^{\mathrm{III}}$ sites. The CTPT also provides a lower $T_{\mathrm{C}}$ for LTP with the spin configuration of $\mathrm{Fe}^{\mathrm{II}}(S=0)-\mathrm{Fe}^{\mathrm{III}}(S=5 / 2)$ compared with the $T_{\mathrm{C}}$ for HTP with the spin configuration of $\mathrm{Fe}^{\mathrm{II}}(S=2)-\mathrm{Fe}^{\mathrm{III}}(S=1 / 2)$. The magnetic interaction in the LTP is weaker than that in the HTP because of the diamagnetic nature of $\mathrm{Fe}^{\mathrm{II}}$ [38].

Moreover, the substitution of diamagnetic $\mathrm{Zn}^{\mathrm{II}}$ for $\mathrm{Fe}^{\mathrm{II}}$ indicated the following behavior. (a) The effective magnetic moment $\left(\mu_{\text {eff }}\right)$ decreases with an increased substituted ratio, $x$, in the temperature range of the paramagnetic region. (b) The CTPT is suppressed by the substitution of $\mathrm{Zn}^{\mathrm{II}}$ for Fe ${ }^{\mathrm{II}}$ at a critical substituted ratio between $x=0.05$ and 0.13 . (c) The $T_{C}$ is once enhanced in the low substituted ratio in $x<0.05$ and then decreases with the increasing of $x$. This peculiar substituted ratio dependence of the $T_{C}$ is explained by the switching between the LTP and HTP with the small amount of substitution with $\mathrm{Zn}^{\mathrm{II}}$.

Based on the characteristic magnetic properties of $\left(n-\mathrm{C}_{3} \mathrm{H}_{7}\right)_{4} \mathrm{~N}\left[\mathrm{Fe}^{\mathrm{II}} \mathrm{Fe}^{\mathrm{III}}(\mathrm{dto})_{3}\right]$ and its $\mathrm{Zn} \mathrm{n}^{\mathrm{II}}$ substituted system, we have investigated the effect of the substitution of $\mathrm{Mn}^{\mathrm{II}}$ for $\mathrm{Fe}^{\mathrm{II}}$ on the CTPT and ferromagnetism.

\subsubsection{Magnetism of $\left(n-\mathrm{C}_{3} \mathrm{H}_{7}\right)_{4} \mathrm{~N}\left[\mathrm{Fe}^{\mathrm{II}}{ }_{1-x} \mathrm{Mn}^{\mathrm{II}}{ }_{x} \mathrm{Fe}^{\mathrm{III}}(\mathrm{dto})_{3}\right]$}

Figure 3 a shows the temperature dependence of the molar magnetic susceptibility multiplied by temperature, $\chi T$, in the $\mathrm{Mn}^{\mathrm{II}}$-substituted system with selected substituted ratios of $x=0.00,0.01$, $0.02,0.77$ and 1.00 . The $\chi T$ values at $300 \mathrm{~K}$ fall into the range of $4.5-5.1 \mathrm{emu} \mathrm{K} \mathrm{mol}{ }^{-1}$. Upon cooling below $50 \mathrm{~K}$, the $\chi T$ values for the complexes with $x \leq 0.77$ increase rapidly to reach a maximum and then decrease. This behavior is the signature of the presence of ferromagnetic ordering in these complexes. As for $x=1.00$, on the other hand, the $\chi T$ value decreases slowly on cooling down to $7 \mathrm{~K}$, then increases toward a small maximum at around $5 \mathrm{~K}$, and then decreases down to $2 \mathrm{~K}$, which is shown in the inset of Figure 3a. As discussed later, the dominant magnetic interaction for $x=1.00$ is a ferromagnetic one; thus, the small maximum at around $5 \mathrm{~K}$ can be attributed to the presence of ferromagnetic ordering. The decrease of $\chi T$ with decreasing temperature, except for the maximum 
point at around $5 \mathrm{~K}$, presumably arises from the orbital contribution of the $\mathrm{Fe}^{\mathrm{III}}$ ion. In connection with this, the following should be noted. In the case of the low-spin state $\left(t_{2 \mathrm{~g}}{ }^{5}, S=1 / 2\right)$ of Fe $\mathrm{e}^{\mathrm{III}}$ with a first-order orbital angular momentum in isolated octahedra, $\mu_{\text {eff }}\left(\mathrm{Fe}^{\mathrm{III}}\right)$ decreases with decreasing temperature [53,54]. In fact, $\mu_{\mathrm{eff}}\left(\mathrm{Fe}^{\mathrm{III}}\right)$ in $\mathrm{KBa}\left[\mathrm{Fe}^{\mathrm{III}}(\mathrm{dto})_{3}\right] \cdot 3 \mathrm{H}_{2} \mathrm{O}$ gradually drops with the temperature decreasing below $50 \mathrm{~K}$ [55].
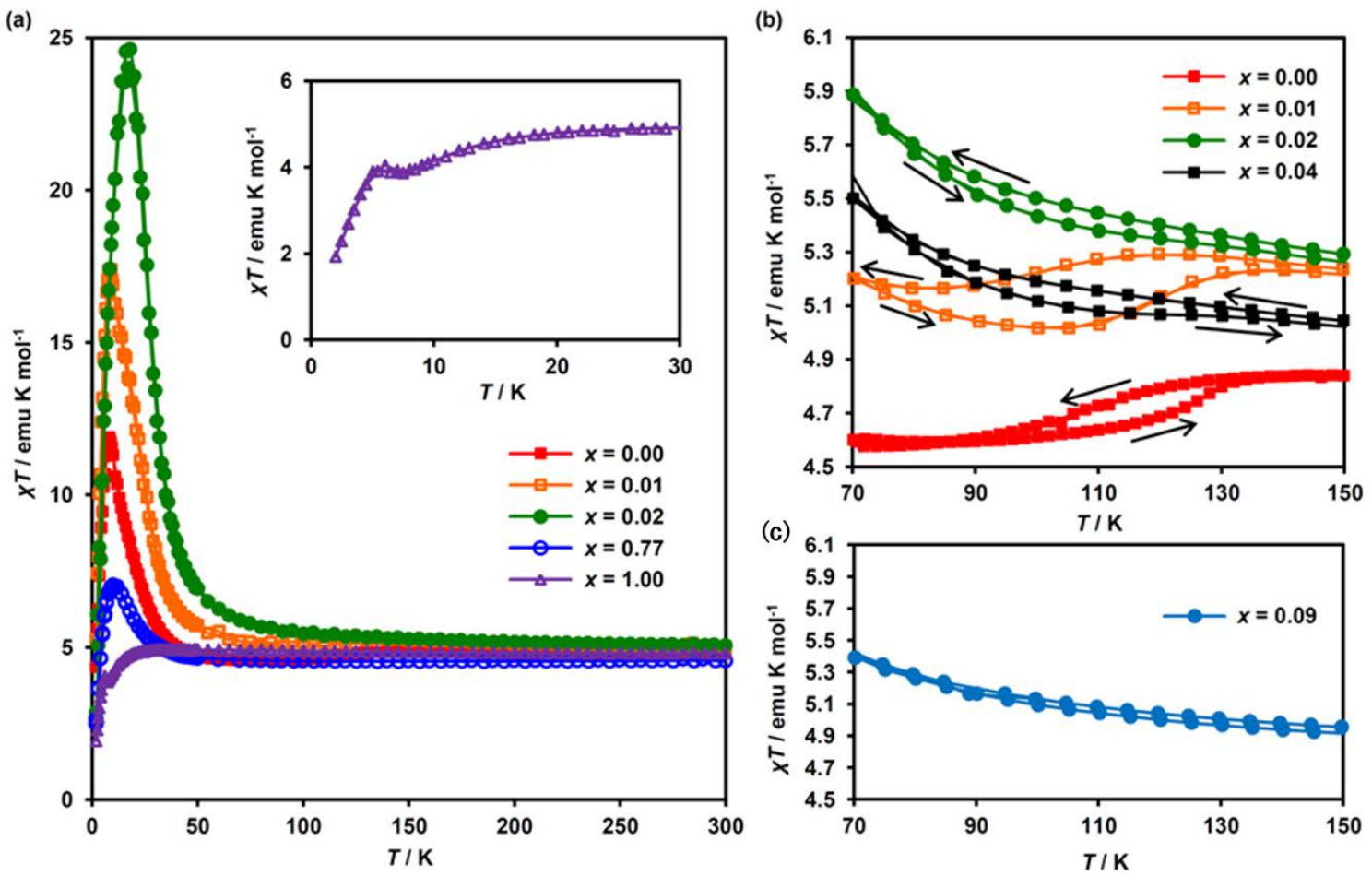

Figure 3. Magnetic behavior of $\left(n-\mathrm{C}_{3} \mathrm{H}_{7}\right)_{4} \mathrm{~N}\left[\mathrm{Fe}^{\mathrm{II}}{ }_{1-x} \mathrm{Mn}_{x}{ }_{x} \mathrm{Fe}^{\mathrm{III}}(\mathrm{dto})_{3}\right]$. (a) Temperature dependence of the molar susceptibility multiplied by temperature $(\chi T)$ for $\left(n-\mathrm{C}_{3} \mathrm{H}_{7}\right)_{4} \mathrm{~N}\left[\mathrm{Fe}^{\mathrm{II}}{ }_{1-x} \mathrm{Mn}^{\mathrm{II}}{ }_{x} \mathrm{Fe}^{\mathrm{III}}(\mathrm{dto})_{3}\right],(\mathbf{b}, \mathbf{c})$ are expanded figures for $x=0.00$ to 0.04 and 0.09 , respectively.

For the complexes with a quite low $\mathrm{Mn}^{\mathrm{II}}$ concentration of $0.00 \leq x \leq 0.04$, the $\chi \mathrm{T}$ curves exhibit a thermal hysteresis owing to the CTPT at around $110 \mathrm{~K}$ (Figure $3 \mathrm{~b}$ ). This thermal hysteresis in $\chi T$ completely disappears for $x \geq 0.09$ (Figure 3c). Furthermore, in the vicinity of the CTPT, a small drop in the $\chi T$ value is observed for $x=0.00$ and 0.01 , which arises from the difference in the $\mu_{\text {eff }}$ between HTP and LTP. These results suggest that the substitution of $\mathrm{Mn}^{\mathrm{II}}$ for $\mathrm{Fe}^{\mathrm{II}}$ successively suppresses the CTPT in the low $\mathrm{Mn}^{\mathrm{II}}$ concentration region and completely suppresses it for $x \geq 0.09$.

The application of the Curie-Weiss law to these data gives the Curie constant, $C$, and the Weiss temperature, $\theta$, for $\left(n-\mathrm{C}_{3} \mathrm{H}_{7}\right)_{4} \mathrm{~N}\left[\mathrm{Fe}^{\mathrm{II}}{ }_{1-x} \mathrm{Mn}^{\mathrm{II}}{ }_{x} \mathrm{Fe}^{\mathrm{III}}(\mathrm{dto})_{3}\right]$. The obtained $C$ value ranges within 4.31-4.86 emu K mol${ }^{-1}$, which is slightly larger than that expected for the spin-only values of the constituent metal ions, $\mathrm{Fe}^{\mathrm{II}}(S=2), \mathrm{Mn}^{\mathrm{II}}(S=5 / 2)$ and $\mathrm{Fe}^{\mathrm{III}}(S=1 / 2)$. This difference can be explained by the anisotropic $g$-value of $\mathrm{Fe}^{\mathrm{II}}$ as mentioned in the previous work [38]. Figure 4 shows the $\mathrm{Mn}^{\mathrm{II}}$-substituted ratio, with $x$ dependent on the Weiss temperature, $\theta$. Although the $\theta$ value tends to decrease with increasing $\mathrm{Mn}^{\mathrm{II}}$ concentration, it remains positive over the whole $x$ range. 


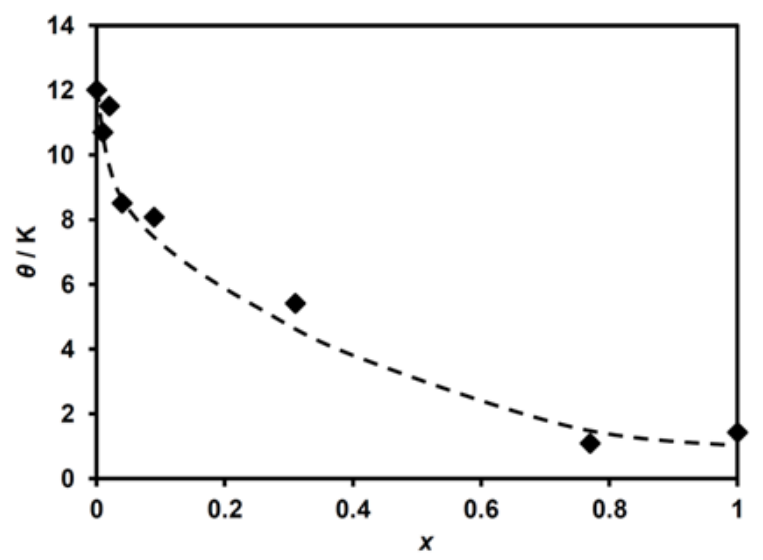

Figure 4. Weiss temperature as a function of substituted ratio $(x)$ for $\left(n-\mathrm{C}_{3} \mathrm{H}_{7}\right)_{4} \mathrm{~N}\left[\mathrm{Fe}^{\mathrm{II}}{ }_{1-x} \mathrm{Mn}_{x}{ }_{x} \mathrm{Fe}^{\mathrm{III}}(\mathrm{dto})_{3}\right]$.

In order to elucidate the ferromagnetic phase transition in this system, we investigated the temperature dependences of the FCM, ZFCM and RM. These results are shown in Figure 5. For $x=$ 0.00 (i.e., $\left.\left(n-\mathrm{C}_{3} \mathrm{H}_{7}\right)_{4} \mathrm{~N}\left[\mathrm{Fe}^{\mathrm{II}} \mathrm{Fe}^{\mathrm{III}}(\mathrm{dto})_{3}\right]\right)$, a ferromagnetic phase transition occurred at $T_{\mathrm{C}}=7 \mathrm{~K}$, being estimated from the bifurcation of the FCM and ZFCM curves and the vanishing point of the RM (Figure 5a). For $x=0.01$, a slight splitting between FCM and ZFCM curves in addition to non-zero RM was observed below $12 \mathrm{~K}$, while a large deviation of these curves was found below $7 \mathrm{~K}$ (Figure $5 \mathrm{~b}$ ). Such a two-step transition behavior in FCM and ZFCM implies the coexistence of two ferromagnetic phases accompanied by an incomplete CTPT. It should be noted that the diamagnetic low-spin state of $\mathrm{Fe}^{\mathrm{II}}$ in the LTP fragment is responsible for the lower $T_{\mathrm{C}}$ value. A similar two-step transition also progresses in the complexes for $x=0.02$ and 0.04 ( Figure $5 c, d$ ). The $T_{C}$ values for the HTP fragment in these complexes apparently increased, which are estimated to be 20 and $15 \mathrm{~K}$, respectively. Meanwhile, the lower $T_{C}$ values derived from the LTP fragment are supposed to be almost invariant. This implies that the $\mathrm{Mn}^{\mathrm{II}}$ substitution does not affect the magnetism of the LTP. For $x \geq 0.09$, the lower-temperature transition corresponding to the LTP fragment disappears (Figure 5e-h) owing to the absence of the CTPT. The $T_{\mathrm{C}}$ values for these complexes are estimated at $12 \mathrm{~K}, 10 \mathrm{~K}, 5 \mathrm{~K}$ and $4 \mathrm{~K}$ for $x=0.09,0.31,0.77$ and 1.00 , respectively.

To further confirm the coexistence of two ferromagnetic phases and to determine $T_{C}$, the ac magnetic susceptibility measurements were performed for $x=0.00-0.04$. The temperature dependences of the in-phase signal $\left(\chi^{\prime}\right)$ and out-of-phase one $\left(\chi^{\prime \prime}\right)$ are shown in Figure 6. For $x=0.01$, the $\chi^{\prime}$ peaks were observed as broad maxima at $15 \mathrm{~K}$ and $7 \mathrm{~K}$, together with the increased $\chi^{\prime \prime}$ value foreshowing a maximum or shoulder peak, which corresponds to the development of a ferromagnetic ordered state coming from the HTP component (Figure $6 b$ ). Similarly, we can evaluate the $T_{\mathrm{C}} \mathrm{s}$ of the HTP and LTP for $x=0.02$ and 0.04 as $16 \mathrm{~K}$ and $7 \mathrm{~K}$, respectively (Figure $6 \mathrm{c}, \mathrm{d}$ ). These data clearly confirm the presence of two ferromagnetic phases for $x=0.01,0.02$ and 0.04 . The $T_{C}$ for the LTP fragment in these complexes are determined to be $7 \mathrm{~K}$, which is identical to the $T_{C}$ value for $x=0.00$ (Figure 6a). Such an independence of the $T_{C}$ value for the LTP fragment on the $\mathrm{Mn}^{\mathrm{II}}$-substituted ratio indicates that the vicinity of the dopant $\mathrm{Mn}^{\mathrm{II}}$ ions is no longer in the LTP spin state because of the suppression of the CTPT, and hence the ferromagnetic phase transition in the LTP component in $\left(n-\mathrm{C}_{3} \mathrm{H}_{7}\right)_{4} \mathrm{~N}\left[\mathrm{Fe}^{\mathrm{II}}{ }_{1-x} \mathrm{Mn}^{\mathrm{II}}{ }_{x} \mathrm{Fe}^{\mathrm{III}}(\mathrm{dto})_{3}\right]$ is unaffected by dopant $\mathrm{Mn}^{\mathrm{II}}$ ions. In connection with this, it should be noted that similar behavior has already been reported for the magnetic dilution system, $\left(n-\mathrm{C}_{3} \mathrm{H}_{7}\right)_{4} \mathrm{~N}\left[\mathrm{Fe}^{\mathrm{II}}{ }_{1-x} \mathrm{Zn}^{\mathrm{II}}{ }_{x} \mathrm{Fe}^{\mathrm{III}}(\mathrm{dto})_{3}\right][40,41]$. 

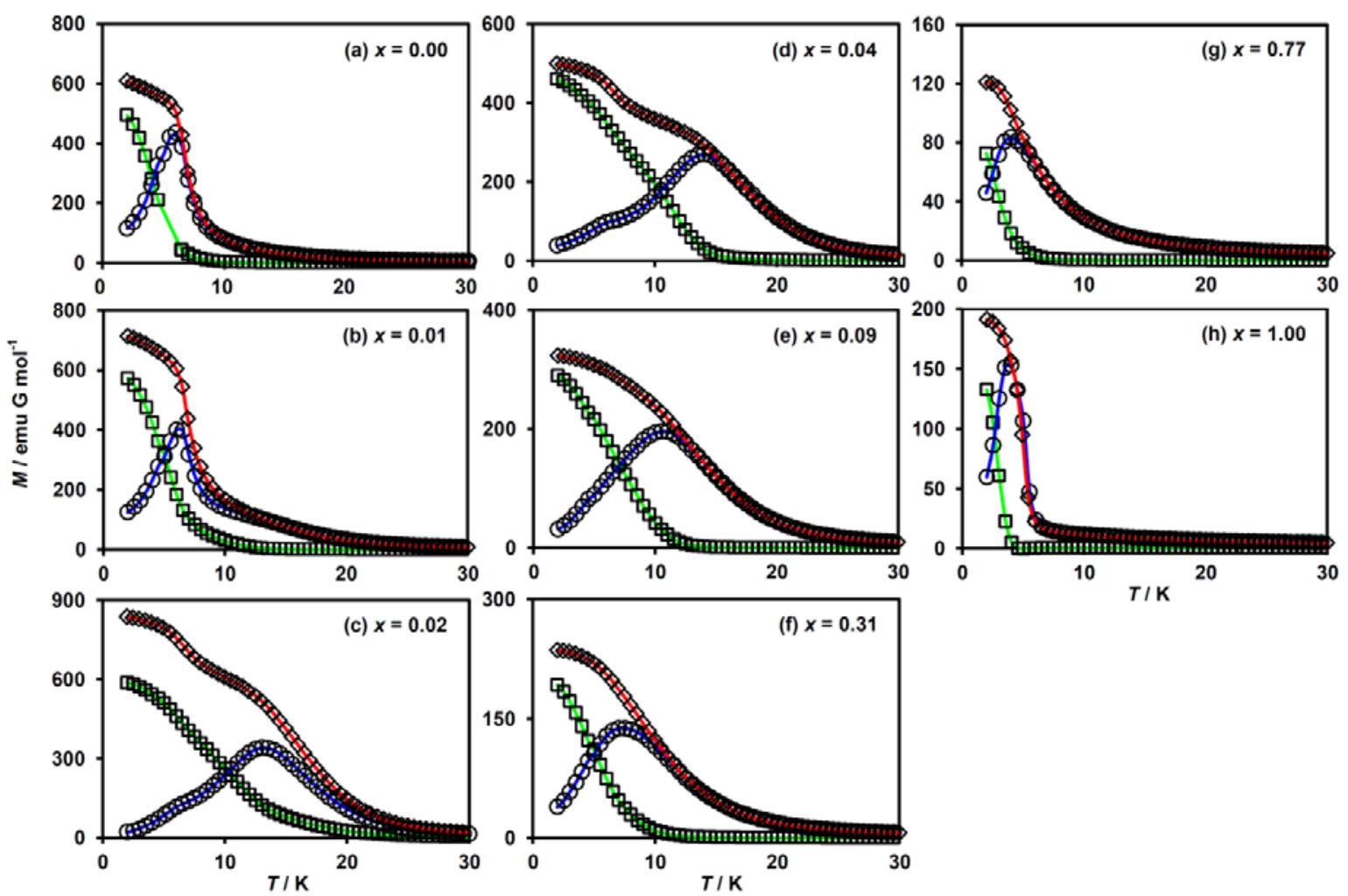

Figure 5. Temperature dependence of magnetization for $\left(n-\mathrm{C}_{3} \mathrm{H}_{7}\right)_{4} \mathrm{~N}\left[\mathrm{Fe}^{\mathrm{II}}{ }_{1-x} \mathrm{Mn}^{\mathrm{II}}{ }_{x} \mathrm{Fe}^{\mathrm{III}}(\mathrm{dto})_{3}\right]$. FC (rhombus): field-cooled, ZFC (circle): zero-field-cooled and RM (square): remnant magnetization. $H=$ 30 Oe. $(\mathbf{a}-\mathbf{h})$ These figures correspond to the magnetization curves for $x=0.00,0.01,0.02,0.04,0.09,0.31$, 0.77 and 1.00 , respectively.
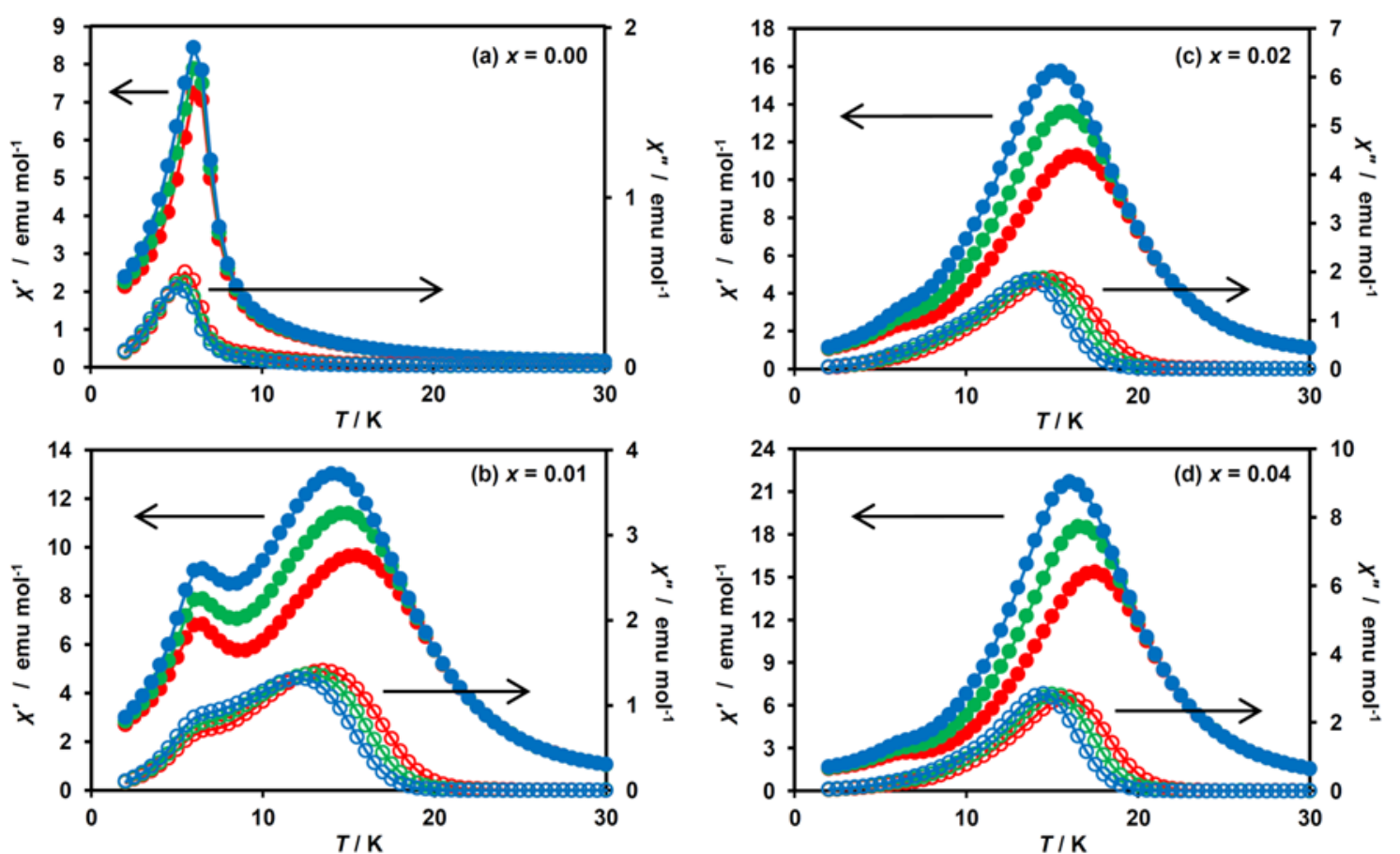

Figure 6. Temperature dependences of the in-phase $\left(\chi^{\prime}\right.$, filled circle) and out-of-phase ( $\chi^{\prime \prime}$, open circle) ac magnetic susceptibilities for $\left(n-\mathrm{C}_{3} \mathrm{H}_{7}\right)_{4} \mathrm{~N}\left[\mathrm{Fe}^{\mathrm{II}}{ }_{1-x} \mathrm{Mn}^{\mathrm{II}}{ }_{x} \mathrm{Fe}^{\mathrm{III}}(\mathrm{dto})_{3}\right]$ at 10 (blue), 100 (green) and $1000 \mathrm{~Hz}$ (red). (a-d) These figures correspond to the magnetization curves for $\mathrm{x}=0.00,0.01,0.02$ and 0.04 , respectively. 


\subsubsection{Dielectric Constant Measurements of $\left(n-\mathrm{C}_{3} \mathrm{H}_{7}\right)_{4} \mathrm{~N}\left[\mathrm{Fe}^{\mathrm{II}}{ }_{1-x} \mathrm{Mn}^{\mathrm{II}}{ }_{x} \mathrm{Fe}^{\mathrm{III}}(\mathrm{dto})_{3}\right]$}

The dielectric constant measurement is suitable to detect the CTPT in the series of $\left(n-\mathrm{C}_{3} \mathrm{H}_{7}\right)_{4} \mathrm{~N}\left[\mathrm{Fe}^{\mathrm{II}}{ }_{1-x} \mathrm{Mn}^{\mathrm{II}}{ }_{x} \mathrm{Fe}^{\mathrm{III}}(\mathrm{dto})_{3}\right]$ as well as the $\mathrm{Zn}^{\mathrm{II}}$-substituted analogues [40,41]. Figure 7 shows the temperature dependence of the dielectric constants $\left(\varepsilon^{\prime}\right)$ for $\left(n-\mathrm{C}_{3} \mathrm{H}_{7}\right)_{4} \mathrm{~N}\left[\mathrm{Fe}^{\mathrm{II}}{ }_{1-x} \mathrm{Mn}^{\mathrm{II}}{ }_{x} \mathrm{Fe}^{\mathrm{III}}(\mathrm{dto})_{3}\right]$ measured at $0.1 \mathrm{MHz}$. For the complexes with a low $\mathrm{Mn}^{\mathrm{II}}$ concentration of $x \leq 0.04$, an anomalous enhancement of $\varepsilon^{\prime}$ accompanied by a thermal hysteresis was observed at around 120 $\mathrm{K}$, which corresponds to the occurrence of the CTPT in these complexes (Figure 7a-d). For the complexes with $x \geq 0.09$, such an anomaly is no longer observed (Figure 7e-h). These results confirm that the complexes in the low $\mathrm{Mn}^{\mathrm{II}}$-substituted region $(0.00 \leq x \leq 0.04)$ exhibit CTPT, whereas it is completely suppressed for $x \geq 0.09$. As a result of the dielectric constant and magnetic measurements, we can define the critical substituted ratio for the disappearance of CTPT, estimated at around $0.09>x$ $>0.04$.

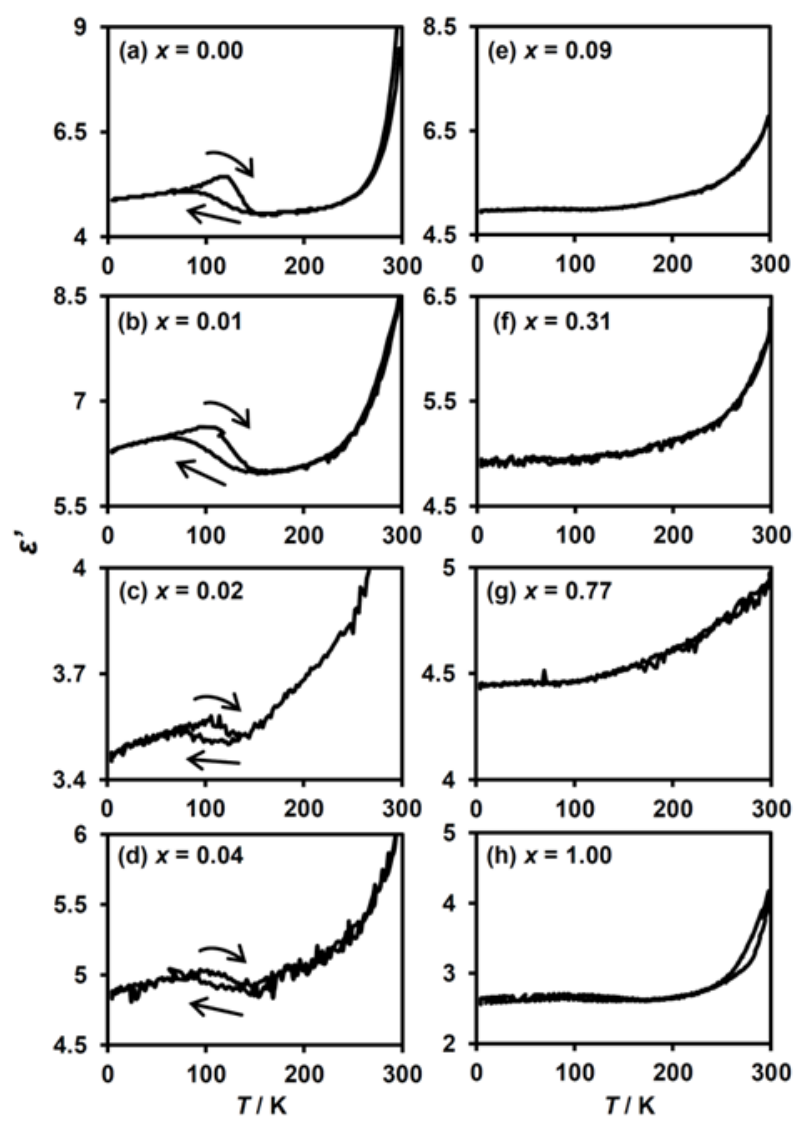

Figure 7. Temperature dependence of the dielectric constant, $\varepsilon^{\prime}$, for $\left(n-\mathrm{C}_{3} \mathrm{H}_{7}\right)_{4} \mathrm{~N}\left[\mathrm{Fe}^{\mathrm{II}}{ }_{1-x} \mathrm{Mn}^{\mathrm{II}}{ }_{x} \mathrm{Fe}^{\mathrm{III}}(\mathrm{dto})_{3}\right]$ at an electric field of $0.1 \mathrm{MHz}$. (a-h) These figures correspond to the magnetization curves for $\mathrm{x}=0.00$, $0.01,0.02,0.04,0.09,0.31,0.77$ and 1.00 , respectively.

\section{Discussion}

As shown in Figure 4 , the $\theta$ value for $\left(n-\mathrm{C}_{3} \mathrm{H}_{7}\right)_{4} \mathrm{~N}\left[\mathrm{Fe}^{\mathrm{II}}{ }_{1-x} \mathrm{Mn}^{\mathrm{II}}{ }_{x} \mathrm{Fe} e^{\mathrm{III}}(\mathrm{dto})_{3}\right]$ decreases abruptly in the low $\mathrm{Mn}^{\mathrm{II}}$ concentration ratio of $x$ and tends to decrease monotonically with increasing $\mathrm{Mn}^{\mathrm{II}}$ concentration, while $\theta$ remains positive even at $x=1.00$. This result indicates the ferromagnetic exchange coupling of the nearest neighbor $\mathrm{Mn}^{\mathrm{II}}-\mathrm{Fe}^{\mathrm{III}}$ pair as well as the $\mathrm{Fe}^{\mathrm{II}}-\mathrm{Fe}^{\mathrm{III}}$ one.

Figure 8 shows the schematic mechanism of ferromagnetic ordering for the LTP and HTP of $\left(n-\mathrm{C}_{3} \mathrm{H}_{7}\right)_{4} \mathrm{~N}\left[\mathrm{Fe}^{\mathrm{II}} \mathrm{Fe}^{\mathrm{III}}(\mathrm{dto})_{3}\right]$ and $\left(n-\mathrm{C}_{3} \mathrm{H}_{7}\right)_{4} \mathrm{~N}\left[\mathrm{Mn}^{\mathrm{II}} \mathrm{Fe}^{\mathrm{III}}(\mathrm{dto})_{3}\right]$. As mentioned in the previous literature $[38,56]$, the LTP contains the low-spin state of $\mathrm{Fe}^{\mathrm{II}}\left(t_{2 \mathrm{~g}}{ }^{6}: S=0\right)$ and the high-spin state of $\mathrm{Fe}^{\mathrm{III}}\left(t_{2 \mathrm{~g}}{ }^{4} \mathrm{e}_{\mathrm{g}}{ }^{2}: S=5 / 2\right)$, respectively, where the super-exchange interaction via the continuous 
bridging structure of $\mathrm{Fe}^{\mathrm{III}}-\mathrm{dto}-\mathrm{Fe}^{\mathrm{II}}-\mathrm{dto}-\mathrm{Fe}^{\mathrm{III}}$ is presumably very small and antiferromagnetic if 3D electrons are localized. In the case of the LTP of $\left(n-\mathrm{C}_{3} \mathrm{H}_{7}\right)_{4} \mathrm{~N}\left[\mathrm{Fe}^{\mathrm{II}} \mathrm{Fe}^{\mathrm{III}}(\mathrm{dto})_{3}\right]$, the charge transfer interaction between the $\mathrm{Fe}^{\mathrm{II}}$ and $\mathrm{Fe}^{\mathrm{III}}$ sites gives a perturbation to the wave function of the ground state; therefore, the wave function can be described as $\Psi=\sqrt{1-\alpha^{2}}\left\{\varphi_{i}\left(\mathrm{Fe}^{\mathrm{II}}\left(t_{2 \mathrm{~g}}{ }^{6}\right)\right) \varphi_{j}\left(\mathrm{Fe}^{\mathrm{III}}\left(t_{2 \mathrm{~g}}{ }^{3} e_{\mathrm{g}}{ }^{2}\right)\right)\right\}+$ $\alpha\left\{\varphi_{i}\left(\mathrm{Fe}^{\mathrm{III}}\left(t_{2 \mathrm{~g}}{ }^{5}\right)\right) \varphi_{j}\left(\mathrm{Fe}^{\mathrm{II}}\left(t_{2 \mathrm{~g}}{ }^{4} e_{\mathrm{g}}{ }^{2}\right)\right)\right\}$, where $\alpha$ denotes the normalization coefficient for the component of charge transfer interaction. Each Fe ${ }^{\mathrm{III}}$ site in LTP accepts a $t_{2 \mathrm{~g}}$ electron with down spin, because both of the $t_{2 \mathrm{~g}}$ and $e_{\mathrm{g}}$ orbitals in the $\mathrm{Fe}^{\mathrm{III}}$ site are half occupied. Therefore, the perturbed term of $\varphi_{i}\left(\mathrm{Fe}^{\mathrm{III}}\left(t_{2 \mathrm{~g}}{ }^{5}\right)\right) \varphi_{j}\left(\mathrm{Fe}^{\mathrm{II}}\left(t_{2 \mathrm{~g}}{ }^{4} e_{\mathrm{g}}{ }^{2}\right)\right)$ achieves the ferromagnetic coupling between the spin configuration of $\mathrm{Fe}^{\mathrm{II}}$ and $\mathrm{Fe}^{\mathrm{III}}$. Consequently, the coupling between the ground configuration of $\varphi_{i}\left(\mathrm{Fe}^{\mathrm{II}}\left(t_{2 \mathrm{~g}}{ }^{6}\right)\right) \varphi_{j}\left(\mathrm{Fe}^{\mathrm{III}}\left(t_{2 \mathrm{~g}}{ }^{3} e_{\mathrm{g}}{ }^{2}\right)\right)$ and the forward charge transfer configuration of $\varphi_{i}\left(\mathrm{Fe}^{\mathrm{III}}\left(t_{2 \mathrm{~g}}{ }^{5}\right)\right) \varphi_{j}\left(\mathrm{Fe}^{\mathrm{II}}\left(t_{2 \mathrm{~g}}{ }^{4} e_{\mathrm{g}}{ }^{2}\right)\right)$ stabilizes the ground state and therefore favors the ferromagnetic ordering. In this way, the charge transfer between the $\mathrm{Fe}^{\mathrm{II}}(S=0)$ and $\mathrm{Fe}^{\mathrm{III}}(S=5 / 2)$ sites induces the ferromagnetic ordering in the LTP.

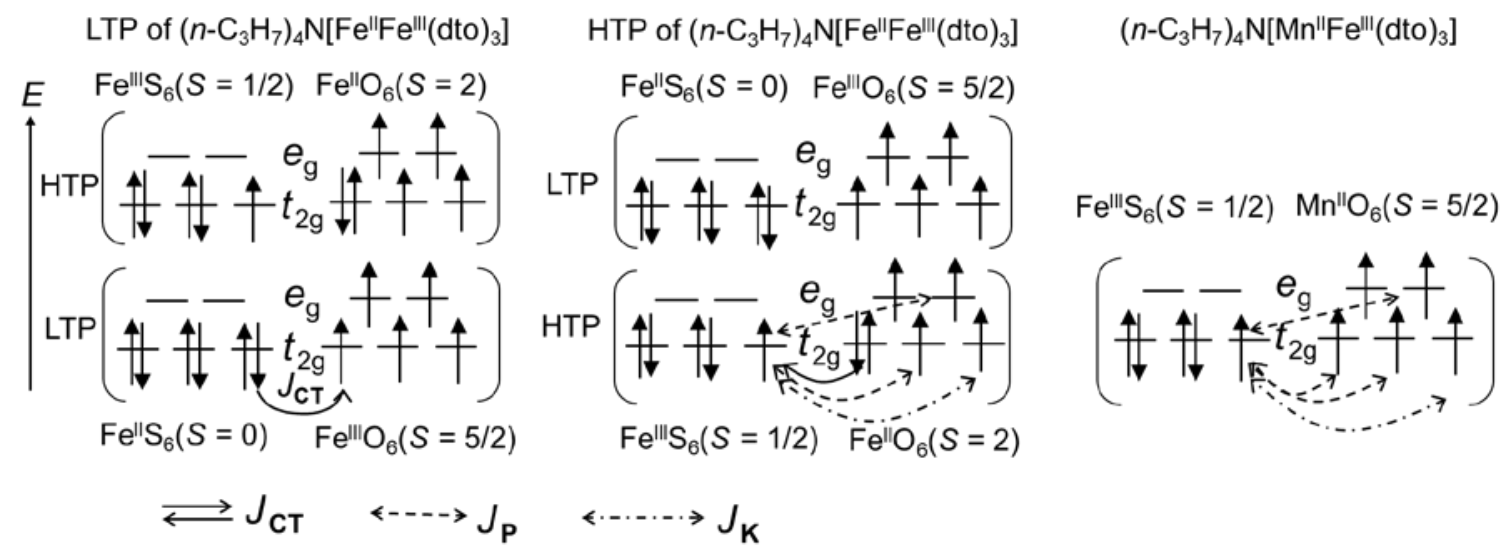

Figure 8. Origin of the ferromagnetic ordering for the LTP and HTP of $\left(n-\mathrm{C}_{3} \mathrm{H}_{7}\right)_{4} \mathrm{~N}\left[\mathrm{Fe}^{\mathrm{II}} \mathrm{Fe}{ }^{\mathrm{III}}(\mathrm{dto})_{3}\right]$ and $\left(n-\mathrm{C}_{3} \mathrm{H}_{7}\right)_{4} \mathrm{~N}\left[\mathrm{Mn}^{\mathrm{II}} \mathrm{Fe}^{\mathrm{III}}(\mathrm{dto})_{3}\right]$. $J_{\mathrm{CT}}, J_{\mathrm{P}}$, and $J_{\mathrm{K}}$ indicate the charge transfer interaction, potential exchange interaction, and kinetic exchange interaction, respectively.

In the case of the HTP fragment of $\left(n-\mathrm{C}_{3} \mathrm{H}_{7}\right)_{4} \mathrm{~N}\left[\mathrm{Fe}^{\mathrm{II}} \mathrm{Fe}^{\mathrm{III}}(\mathrm{dto})_{3}\right]$, each $\mathrm{Fe}{ }^{\mathrm{III}}$ site with a low-spin state $\left(t_{2 g}{ }^{5}: S=1 / 2\right)$ accepts a $t_{2 g}$ electron with down spin from the adjacent $\mathrm{Fe}^{\mathrm{II}}$ site with a high-spin state $\left(t_{2 \mathrm{~g}}{ }^{4} e_{\mathrm{g}}{ }^{2}: S=2\right)$. Therefore, the hybridization between the ground state of $\varphi_{i}\left(\mathrm{Fe}^{\mathrm{III}}\left(t_{2 \mathrm{~g}}{ }^{5}\right)\right) \varphi_{j}\left(\mathrm{Fe}^{\mathrm{II}}\left(t_{2 \mathrm{~g}}{ }^{4} e_{\mathrm{g}}{ }^{2}\right)\right)$ and the forward charge transfer state of $\varphi_{i}\left(\mathrm{Fe}^{\mathrm{II}}\left(t_{2 \mathrm{~g}}{ }^{6}\right)\right) \varphi_{j}\left(\mathrm{Fe}^{\mathrm{III}}\left(t_{2 \mathrm{~g}}{ }^{3} e_{\mathrm{g}}{ }^{2}\right)\right)$ stabilizes the ground state, which favors the ferromagnetic ordering. Furthermore, in addition to the charge transfer interaction $\left(J_{\mathrm{CT}}\right)$, there are also three potential exchange interactions $\left(J_{\mathrm{P}}\right)$ causing ferromagnetic interaction due to the orbital orthogonality and one kinetic exchange interaction $\left(J_{\mathrm{K}}\right)$ causing antiferromagnetic interaction due to the orbital overlap between the adjacent $\mathrm{Fe}^{\mathrm{III}} \mathrm{S}_{6}$ and $\mathrm{Fe}^{\mathrm{II}} \mathrm{O}_{6}$ sites. The sum of $J_{\mathrm{CT}}$ and $J_{\mathrm{P}}$ is considered to be stronger than $J_{\mathrm{K}}$, which is responsible for the ferromagnetic ordering with higher $T_{\mathrm{C}}$ for the HTP fragment of $\left(n-\mathrm{C}_{3} \mathrm{H}_{7}\right)_{4} \mathrm{~N}\left[\mathrm{Fe}^{\mathrm{II}} \mathrm{Fe}^{\mathrm{III}}(\mathrm{dto})_{3}\right]$.

In the case of $\left(n-\mathrm{C}_{3} \mathrm{H}_{7}\right)_{4} \mathrm{~N}\left[\mathrm{Mn}^{\mathrm{II}} \mathrm{Fe}^{\mathrm{III}}(\mathrm{dto})_{3}\right]$, there are four $J_{\mathrm{PS}}$ and one $J_{\mathrm{K}}$. The sum of the potential exchange interaction is considered to be stronger than the kinetic exchange interaction, which is responsible for the ferromagnetic ordering. Actually, the ferromagnetic ordering of $\left(n-\mathrm{C}_{3} \mathrm{H}_{7}\right)_{4} \mathrm{~N}\left[\mathrm{Mn}^{\mathrm{II}} \mathrm{Fe}^{\mathrm{III}}(\mathrm{dto})_{3}\right]$ has already been reported by Carling et al. [57], in which both $T_{\mathrm{C}}$ and $\theta$ were estimated at $10 \mathrm{~K}$ from the analysis of $1 / \chi$ as a function of temperature.

$T_{\mathrm{C}}$ as a function of $x$ for $\left(n-\mathrm{C}_{3} \mathrm{H}_{7}\right)_{4}\left[\mathrm{Fe}^{\mathrm{II}}{ }_{1-x} \mathrm{Mn}_{x} \mathrm{Fe}^{\mathrm{II}} \mathrm{Fe}^{\mathrm{III}}(\mathrm{dto})_{3}\right]$ is shown in Figure 9 . An enhancement of $T_{\mathrm{C}}$ from $7 \mathrm{~K}$ to $20 \mathrm{~K}$ ( $x=0.00$ to 0.02$)$ is ascribed to the appearance of the HTP fragment exhibiting the higher $T_{C}$. As with the case of $\left(n-\mathrm{C}_{3} \mathrm{H}_{7}\right)_{4}\left[\mathrm{Fe}^{\mathrm{II}}{ }_{1-x} \mathrm{Zn}_{x}{ }_{x} \mathrm{Fe}^{\mathrm{III}}(\mathrm{dto})_{3}\right][40,41]$, the LTP fragment is unaffected by dopant $\mathrm{Mn}^{\mathrm{II}}$ ions, and thus the LTP fragment in all these complexes possesses the same $T_{C}$ value of $7 \mathrm{~K}$. With the further increasing of $x$ above $0.04, T_{C}$ decreases monotonically, corresponding to the lowering of the ferromagnetic interaction, to reach a minimum value of $4 \mathrm{~K}$ for $x=1.00$. 


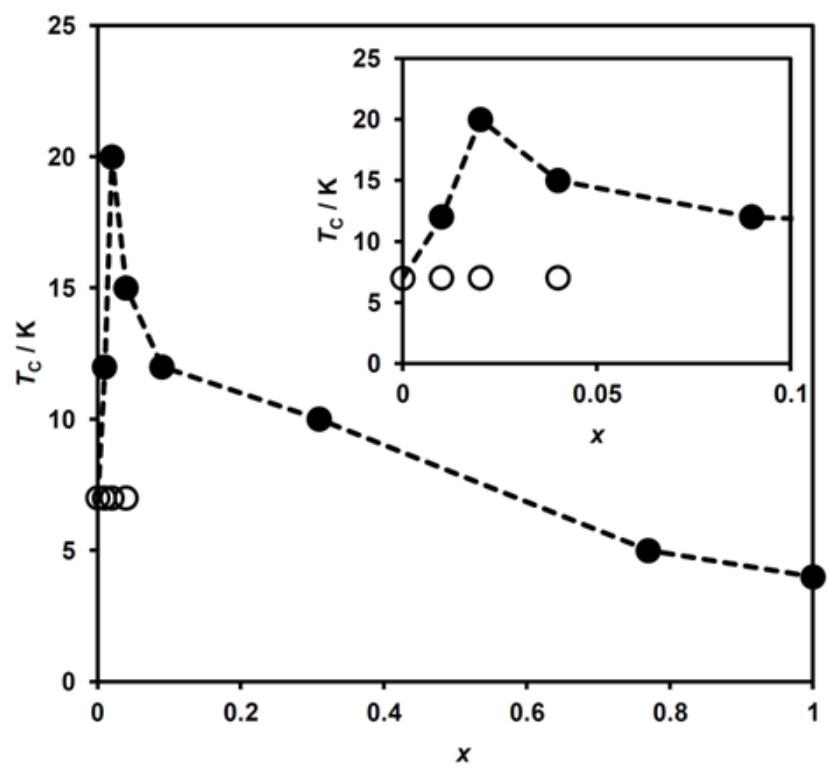

Figure 9. Variation of the ferromagnetic transition temperature $\left(T_{C}\right)$ with $x$ for $\left(n-\mathrm{C}_{3} \mathrm{H}_{7}\right)_{4} \mathrm{~N}\left[\mathrm{Fe}^{\mathrm{II}}{ }_{1-x} \mathrm{Mn}^{\mathrm{II}}{ }_{x} \mathrm{Fe}^{\mathrm{III}}(\mathrm{dto})_{3}\right]$ in $(\bullet)$ the high-temperature phase and $(\bigcirc)$ low-temperature phase. Inset shows the extended figure in the low $\mathrm{Mn}^{\mathrm{II}}$ concentration region. The dashed lines are a guide for the eyes.

The detection of the CTPT can be achieved by both the magnetic susceptibility and dielectric constant measurements. From the results of magnetic susceptibility and dielectric constant measurements, the phase diagram for $\left(n-\mathrm{C}_{3} \mathrm{H}_{7}\right)_{4}\left[\mathrm{Fe}^{\mathrm{II}}{ }_{1-x} \mathrm{Mn}^{\mathrm{II}}{ }_{x} \mathrm{Fe}^{\mathrm{III}}(\mathrm{dto})_{3}\right]$ is determined as shown in Figure 10. The legends in this diagram were assigned as follows. $T_{C}(\mathrm{HTP}$ or LTP): the ferromagnetic transition temperature for the HTP or LTP, determined by the FCM, ZFCM, and RM measurements; $T_{\uparrow}$ or $T_{\downarrow}(\mathrm{CT})$ : the upper or lower limit of the thermal hysteresis in the dielectric constant measurement; $\mathrm{P}_{\mathrm{HTP}}$ or $\mathrm{F}_{\mathrm{HTP}}$ : paramagnetic or ferromagnetic phase with the HTP spin configuration; $\mathrm{P}_{\text {mix }}$ or $\mathrm{F}_{\text {mix }}$ : paramagnetic or ferromagnetic phase with a mixed state of the HTP and LTP spin configuration, respectively.

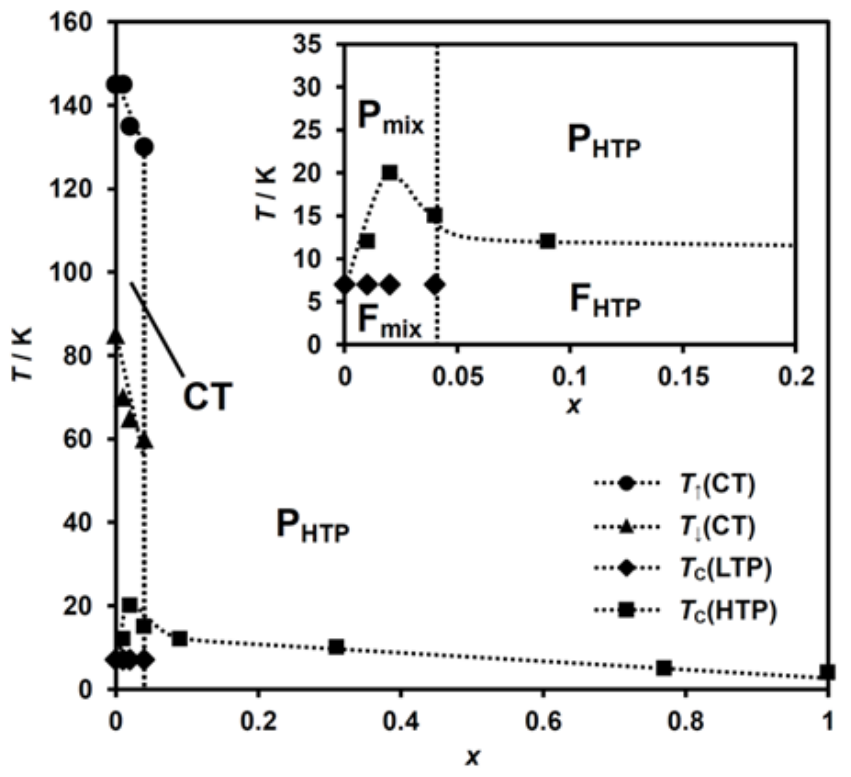

Figure 10. Phase diagram of $\left(n-\mathrm{C}_{3} \mathrm{H}_{7}\right)_{4} \mathrm{~N}\left[\mathrm{Fe}^{\mathrm{II}}{ }_{1-x} \mathrm{Mn}^{\mathrm{II}}{ }_{x} \mathrm{Fe}^{\mathrm{III}}(\mathrm{dto})_{3}\right]$. 
As shown in Figure 10, the paramagnetic phase corresponding to the HTP $\left(\mathrm{P}_{\mathrm{HTP}}\right)$ appears within the whole $\mathrm{Mn}^{\mathrm{II}}$ concentration region at room temperature. The $\mathrm{Mn}^{\mathrm{II}}$-substituted complexes with the low $x$ values of $0.00 \leq x \leq 0.04$ exhibit the CT phase in the temperature range between $T_{\uparrow}(\mathrm{CT})$ and $T_{\downarrow}(\mathrm{CT})$. In this region, the CTPT raises the dynamic oscillation between $\mathrm{Fe}^{\mathrm{II}}$ and $\mathrm{Fe}^{\mathrm{III}}$, which is found by $\mu S R$ measurement $[58,59]$. Below $T_{\downarrow}(\mathrm{CT})$, the paramagnetic phase for the complexes with $0.00<x$ $\leq 0.04$, which is denoted as $\mathrm{P}_{\text {mix }}$ in Figure 10, becomes the mixing state between the LTP and HTP as a result of the partial suppression of the CTPT. The complexes in this $x$ region undergo a ferromagnetic phase transition within the HTP domain at $T_{\mathrm{C}}(\mathrm{HTP})$, below which the ferromagnetic phase with a spin state of a mixture of the LTP and HTP $\left(\mathrm{F}_{\text {mix }}\right)$ appears as already mentioned in Section 3.2.2. The complexes with further high $x$ region (i.e. $x>0.04$ ) stay in the $\mathrm{P}_{\text {HTP }}$ phase down to $T_{\mathrm{C}}(\mathrm{HTP})$, reflecting the complete suppression of the CTPT, and undergo a ferromagnetic phase transition within the HTP spin state at this temperature. Below $T_{\mathrm{C}}(\mathrm{HTP})$, the complexes in this $x$ region are in the ferromagnetic phase with the spin state of the HTP $\left(\mathrm{F}_{\mathrm{HTP}}\right)$.

Although the phase diagram of the magnetically substituted complexes $\left(n-\mathrm{C}_{3} \mathrm{H}_{7}\right)_{4} \mathrm{~N}\left[\mathrm{Fe}^{\mathrm{II}}{ }_{1-x} \mathrm{Mn}^{\mathrm{II}}{ }_{x} \mathrm{Fe}{ }^{\mathrm{III}}(\mathrm{dto})_{3}\right]$ is essentially similar to that for $\left(n-\mathrm{C}_{3} \mathrm{H}_{7}\right)_{4} \mathrm{~N}\left[\mathrm{Fe}^{\mathrm{II}}{ }_{1-x} \mathrm{Zn}_{x}{ }_{x} \mathrm{Fe}^{\mathrm{III}}(\mathrm{dto})_{3}\right]$, the major difference between these two systems is the ferromagnetic ordering in the high dopant concentration region; i.e., the ferromagnetic phase appears in the whole $\mathrm{Mn}^{\mathrm{II}}$ concentration range in the present case, while it was not found for $\left(n-\mathrm{C}_{3} \mathrm{H}_{7}\right)_{4} \mathrm{~N}\left[\mathrm{Fe}^{\mathrm{II}}{ }_{1-x} \mathrm{Zn}^{\mathrm{II}}{ }_{x} \mathrm{Fe}^{\mathrm{III}}(\mathrm{dto})_{3}\right][40,41]$. The disappearance of the ferromagnetic phase in the latter case is a result of the disconnection of the ferromagnetic exchange pathway by $\mathrm{Zn}^{\mathrm{II}}$-substitution, since there is no magnetic interaction between $\mathrm{Fe}^{\mathrm{III}}$ and nonmagnetic $\mathrm{Zn}^{\mathrm{II}}$. In contrast to this, on the basis of the analysis of the magnetic data, the ferromagnetic interaction between $\mathrm{Mn}^{\mathrm{II}}$ and $\mathrm{Fe}{ }^{\mathrm{III}}$ through the dto bridge in $\left(n-\mathrm{C}_{3} \mathrm{H}_{7}\right)_{4} \mathrm{~N}\left[\mathrm{Fe}^{\mathrm{II}}{ }_{1-x} \mathrm{Mn}^{\mathrm{II}}{ }_{x} \mathrm{Fe}^{\mathrm{III}}(\mathrm{dto})_{3}\right]$ is operating, though weaker than that for $\mathrm{Fe}^{\mathrm{II}}-\mathrm{Fe}^{\mathrm{III}}$, and hence the ferromagnetic exchange pathway is maintained over the whole substitution range. This feature is responsible for the existence of the ferromagnetic phase across the whole substitution range in the phase diagram of this system.

Moreover, the critical substituted ratio for the disappearance of the CTPT is unexpectedly low compared with that for the series of $\mathrm{Zn}^{\mathrm{II}}$-substituted complexes, whose CTPT is completely suppressed in the substituted ratio between $x=0.13$ and $0.26[40,41]$. Considering the ion radii between $\mathrm{Mn}^{\mathrm{II}}$ and $\mathrm{Fe}^{\mathrm{II}}$, the substitution of $\mathrm{Mn}^{\mathrm{II}}$ for $\mathrm{Fe}^{\mathrm{II}}$ tends to expand the honeycomb structure in the magnetic layer of $\left[\mathrm{Fe}^{\mathrm{II}} \mathrm{Fe}^{\mathrm{III}}(\mathrm{dto})_{3}\right]^{-}$. It causes the suppression of HTP in the same manner for the cation-extended complex, $\left(n-\mathrm{C}_{5} \mathrm{H}_{11}\right)_{4} \mathrm{~N}\left[\mathrm{Fe}^{\mathrm{II}} \mathrm{Fe}^{\mathrm{III}}(\mathrm{dto})_{3}\right]$ [38]. A cooperative effect of the CTPT in the low dimensional system has been effectively terminated by the substitution of $\mathrm{Mn}^{\mathrm{II}}$ with remaining the ferromagnetic interaction.

\section{Conclusions}

We investigated the effect of metal substitution on the CTPT and the ferromagnetic phase transition for $\left(n-\mathrm{C}_{3} \mathrm{H}_{7}\right)_{4} \mathrm{~N}\left[\mathrm{Fe}^{\mathrm{II}}{ }_{1-x} \mathrm{Mn}^{\mathrm{II}}{ }_{x} \mathrm{Fe}^{\mathrm{III}}(\mathrm{dto})_{3}\right](x=0-1)$. The existence of the CTPT strongly depends on the $\mathrm{Mn}^{\mathrm{II}}$-substituted ratio of $x$. The series of $\mathrm{Mn}^{\mathrm{II}}$-substituted complexes consist of the structures combined in the space group of $\mathrm{P}_{3}$ and $R 3 \mathrm{c}$ because of the stacking fault between adjacent magnetic layers of $\left[\mathrm{Fe}^{\mathrm{II}}{ }_{1-x} \mathrm{Mn}^{\mathrm{II}}{ }_{x} \mathrm{Fe}^{\mathrm{III}}(\mathrm{dto})_{3}\right]^{-}$. However, since the magnetic behavior is mainly governed by the intralayer magnetic structure, we can discuss the substituted ratio dependence of their physical properties.

From the results of the magnetic and dielectric measurements, the substitution of $\mathrm{Mn}^{\mathrm{II}}$ suppressed the CTPT, leading to the disappearance of CTPT above $x=0.04$. The finding indicates that $\mathrm{Mn}^{\mathrm{II}}$ substitution is more effective at diminishing the CTPT compared with $\mathrm{Zn}^{\mathrm{II}}$ substitution $\left(n-\mathrm{C}_{3} \mathrm{H}_{7}\right)_{4} \mathrm{~N}\left[\mathrm{Fe}^{\mathrm{II}}{ }_{1-x} \mathrm{Zn}_{x}{ }_{x} \mathrm{Fe}^{\mathrm{III}}(\mathrm{dto})_{3}\right]$ (critical substituted ratio: $\left.0.13<x<0.26\right)$ due to the large $\mathrm{Mn}^{\mathrm{II}}$-ion radius in addition to the high cooperativity of the charge transfer phenomenon, as discussed in the case of $\mathrm{Zn}^{\mathrm{II}}$-substituted complexes.

In contrast to such a substitution effect on the CTPT, the ferromagnetic phase was observed in the whole range of $x$ for $\left(n-\mathrm{C}_{3} \mathrm{H}_{7}\right)_{4} \mathrm{~N}\left[\mathrm{Fe}^{\mathrm{II}}{ }_{1-x} \mathrm{Mn}^{\mathrm{II}}{ }_{x} \mathrm{Fe}^{\mathrm{III}}(\mathrm{dto})_{3}\right]$, while it disappears above $x=0.83$ for 
the $\mathrm{Zn}^{\mathrm{II}}$-substituted one. In particular, the ferromagnetic transition temperature $\left(T_{\mathrm{C}}\right)$ was enhanced in a lower region of $x=0.2-0.4$, although the magnetic interaction between $\mathrm{Mn}^{\mathrm{II}}$ and $\mathrm{Fe}^{\mathrm{III}}$ ions is supposed to be weaker than that of $\mathrm{Fe}^{\mathrm{II}}-\mathrm{Fe}^{\mathrm{III}}$ ions considering the estimated Weiss temperatures. Such an enhancement of $T_{C}$ is caused by the increment of the high-temperature phase with the higher $T_{C}$, which originates in the suppression of the CTPT.

The difference between the $\mathrm{Mn}^{\mathrm{II}}$ and $\mathrm{Zn}^{\mathrm{II}}$-substituted complexes is based on the magnetic interaction between $\mathrm{M}^{\mathrm{II}}$ and $\mathrm{Fe}^{\mathrm{III}}$. In the case of the $\mathrm{Zn}^{\mathrm{II}}$-substituted complex, the nonmagnetic $\mathrm{Zn}^{\mathrm{II}}$ prevents the ferromagnetic interaction between the $\mathrm{Fe}^{\mathrm{II}}$ and $\mathrm{Fe}^{\mathrm{III}}$ and induces an antiferromagnetic exchange pathway of $\mathrm{Fe}^{\mathrm{III}}-\mathrm{Zn}^{\mathrm{II}}-\mathrm{Fe}^{\mathrm{III}}$ through the medium of nonmagnetic $\mathrm{Zn}{ }^{\mathrm{II}}$. The antiferromagnetic interaction between $\mathrm{Fe}^{\mathrm{III}}$ and $\mathrm{Fe}^{\mathrm{III}}$ compensates for the ferromagnetic interaction between $\mathrm{Fe}^{\mathrm{II}}$ and $\mathrm{Fe}^{\mathrm{III}}$ at around $x=0.83$, and the $\theta$ becomes zero. Above $x=0.83$, the absolute value of the negative Weiss temperature rapidly increases with increasing $x$. On the other hand, in the case of the $\mathrm{Mn}^{\mathrm{II}}$-substituted complex, both the $\mathrm{Fe}^{\mathrm{II}}$-Fe $\mathrm{Fe}^{\mathrm{III}}$ and $\mathrm{Mn}^{\mathrm{II}}$ - $\mathrm{Fe}^{\mathrm{III}}$ magnetic interactions are ferromagnetic, which is responsible for the positive Weiss temperature in the whole range of $x$, in contrast to the $\mathrm{Zn}^{\mathrm{II}}$-substituted complexes, which is due to the substitution of the magnetic ions.

Author Contributions: Conceptualization, M.E.; methodology, M.E.; validation, M.E., H.I., A.O. and N.K.; formal analysis, H.I. and A.O.; investigation, M.E. and N.K.; resources, M.E.; data curation, H.I., A.O. and M.E.; writing — original draft preparation, M.E.; writing—review and editing, A.O. and N.K.; visualization, M.E.; supervision, M.E.; project administration, M.E.; funding acquisition, M.E.

Funding: This research was funded by a Grant-in-Aid for Young Scientists (No. 19750105) from the Ministry of Education, Culture, Sports, Science and Technology, Japan.

Conflicts of Interest: The authors declare no conflict of interest.

\section{Appendix A}

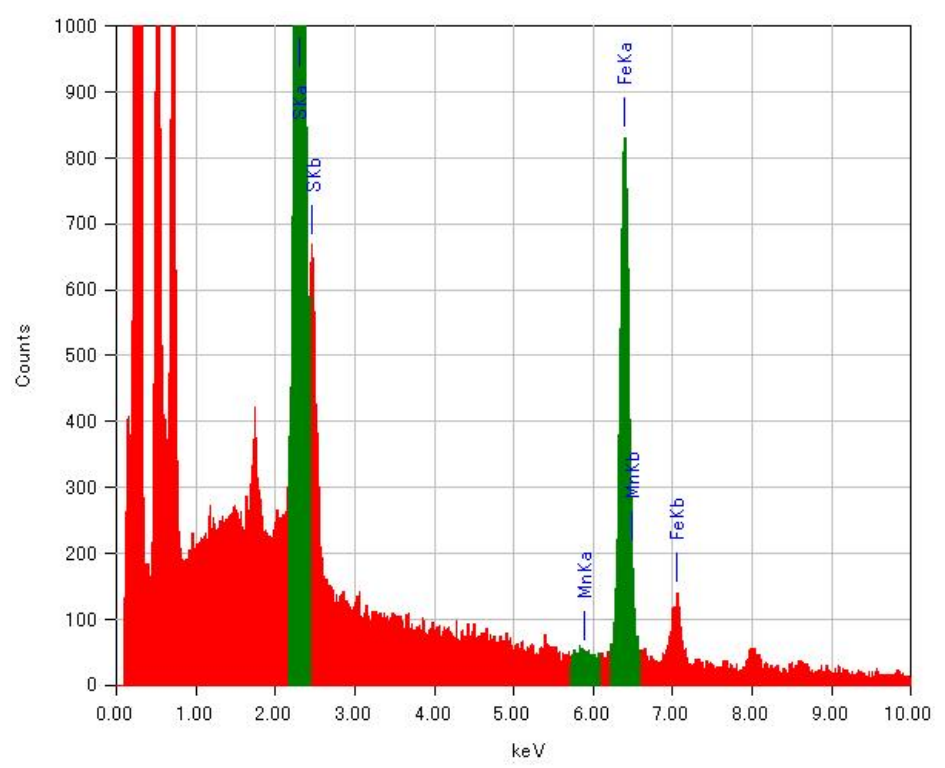

(a)

Figure A1. Cont. 


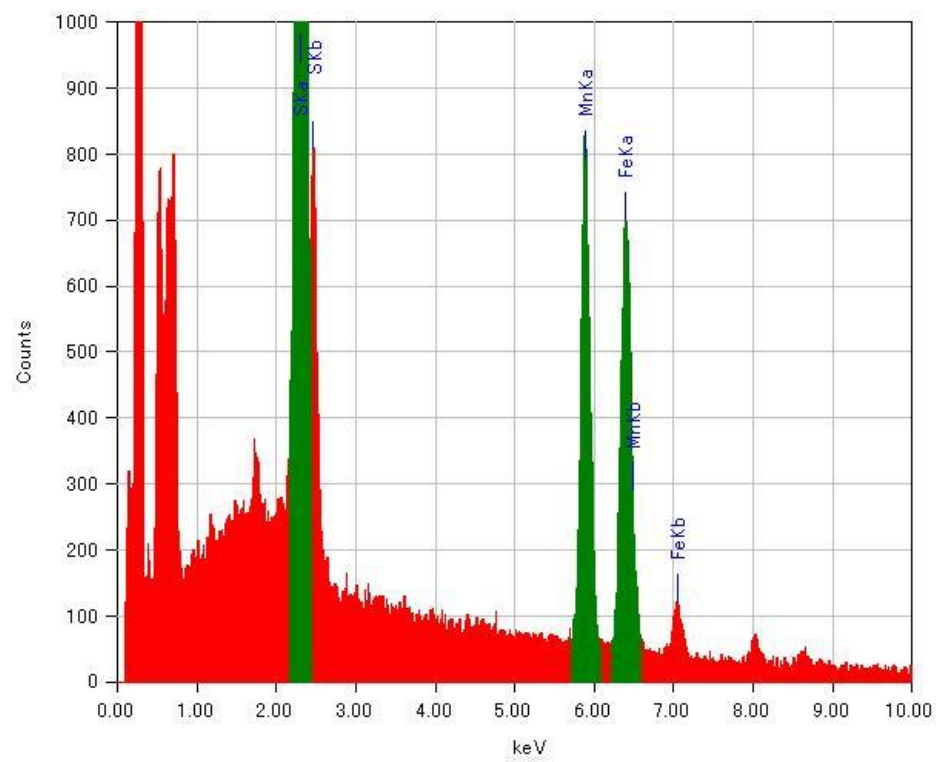

(b)

Figure A1. Energy spectra of EDS for $\left(n-\mathrm{C}_{3} \mathrm{H}_{7}\right)_{4} \mathrm{~N}\left[\mathrm{Fe}^{\mathrm{II}}{ }_{1-x} \mathrm{Mn}^{\mathrm{II}}{ }_{x} \mathrm{Fe}{ }^{\mathrm{III}}(\mathrm{dto})_{3}\right]$ with (a) $x=0$ and (b) $x=1.00$.

\section{References}

1. Castillo, O.; Luque, A.; Sertucha, J.; Román, P.; Lloret, F. Synthesis, Crystal Structure, and Magnetic Properties of a One-Dimensional Polymeric Copper(II) Complex Containing an Unusual 1,1'-Bicoordinated Oxalato Bridge. Inorg. Chem. 2000, 39, 6142-6144. [CrossRef] [PubMed]

2. Kim, J.C.; Cho, J.; Lough, A. Syntheses, isolation, and structures of nickel(II) and copper(II) coordination polymers with a tetraaza macrocyclic ligand. J. Inorg. Chim. Acta 2001, 317, 252-258. [CrossRef]

3. Park, H.; Kim, J.C.; Lough, A.J.; Lee, B.M. One-dimensional macrocyclic zinc(II) coordination polymer containing an unusual bis-monodentate oxalate bridge. Inorg. Chem. Commun. 2007, 10, 303-306. [CrossRef]

4. Kim, J.; Park, A.H.; Kim, J.C.; Lough, A.J.; Pyun, S.Y.; Roh, J.; Lee, B.M. 1D copper(II) and zinc(II) coordination polymers containing an unusual twisted oxalate bridge. Inorg. Chim. Acta 2008, 361, 2087-2093. [CrossRef]

5. Pei, Y.; Journaux, Y.; Kahn, O. Ferromagnetic interactions between $t_{2 \mathrm{~g}}{ }^{3}$ and $e_{\mathrm{g}}{ }^{2}$ magnetic orbitals in a $\mathrm{Cr}^{\mathrm{III}} \mathrm{Ni}_{3}{ }_{3}$ tetranuclear compound. Inorg. Chem. 1989, 28, 100-103. [CrossRef]

6. Ohba, M.; Tamaki, H.; Matsumoto, N.; Ōkawa, H. Oxalate-bridged dinuclear chromium(III)-M(II) (M = copper, nickel, cobalt, iron, manganese) complexes: Synthesis, structure, and magnetism. Inorg. Chem. 1993, 32, 5385-5390. [CrossRef]

7. Glerup, J.; Goodson, P.A.; Hodgson, D.J;; Michelsen, K. Magnetic Exchange through Oxalate Bridges: Synthesis and Characterization of ( $\mu$-Oxalato)dimetal(II) Complexes of Manganese, Iron, Cobalt, Nickel, Copper, and Zinc. Inorg. Chem. 1995, 34, 6255-6264. [CrossRef]

8. Vivas, C.Y.; Delgado, F.S.; Ruiz-Pérez, C.; Julve, M. Preparation and crystal structure of the oxalato-bridged $\mathrm{Cr}^{\mathrm{III}}-\mathrm{Ag}^{\mathrm{I}}$ two-dimensional compound $\left\{\mathrm{Ag}_{3}\left(\mathrm{H}_{2} \mathrm{O}\right)\left[\mathrm{Cr}(\mathrm{dpa})(\mathrm{ox})_{2}\right]_{3}\right\}_{\mathrm{n}} \cdot 2 \mathrm{nH}_{2} \mathrm{O}$ (dpa $=2,2^{\prime}$-dipyridylamine). CrystEngComm 2004, 6, 11-18. [CrossRef]

9. Armentano, D.; De Munno, G.; Lloret, F.; Julve, M. Bis and tris(oxalato)ferrate(III) complexes as precursors of polynuclear compounds. CrystEngComm 2005, 7, 57-66. [CrossRef]

10. Ballester, G.; Coronado, E.; Giménez-Saiz, C.; Romero, F.M. Nitroxide Radicals as Templating Agents in the Synthesis of Magnets Based on Three-Dimensional Oxalato-Bridged Heterodimetallic Networks. Angew. Chem. Int. Ed. 2001, 40, 792-795. [CrossRef]

11. Kahn, O. Dinuclear Complexes with Predictable Magnetic Properties. Angew. Chem. Int. Ed. 1985, 24, 834-850. [CrossRef]

12. Rao, C.N.R.; Natarajan, S.; Vaidhyanathan, R. Metal Carboxylates with Open Architectures. Angew. Chem. Int. Ed. 2004, 43, 1466-1496. [CrossRef] [PubMed] 
13. Clemente-León, M.; Coronado, E.; Martí-Gastaldo, C.; Romero, F.M. Multifunctionality in hybrid magnetic materials based on bimetallic oxalate complexes. Chem. Soc. Rev. 2011, 40, 473-497. [CrossRef] [PubMed]

14. Tamaki, H.; Zhong, Z.J.; Matsumoto, N.; Kida, S.; Koikawa, M.; Achiwa, N.; Hashimoto, Y.; Ōkawa, H. Design of metal-complex magnets. Syntheses and magnetic properties of mixed-metal assemblies $\left\{\mathrm{NBu}_{4}\left[\mathrm{MCr}(\mathrm{ox})_{3}\right]\right\}_{\mathrm{x}}$ $\left(\mathrm{NBu}_{4}{ }^{+}=\right.$tetra(n-butyl)ammonium ion; $\mathrm{ox}^{2-}=$ oxalate ion; $\left.\mathrm{M}=\mathrm{Mn}^{2+}, \mathrm{Fe}^{2+}, \mathrm{Co}^{2+}, \mathrm{Ni}^{2+}, \mathrm{Cu}^{2+}, \mathrm{Zn}^{2+}\right) . \mathrm{J} . \mathrm{Am}$. Chem. Soc. 1992, 114, 6974-6979. [CrossRef]

15. Clemente-León, M.; Coronado, E.; Galán-Mascarós, J.R.; Gómez-García, C.J. Intercalation of decamethylferrocenium cations in bimetallic oxalate-bridged two-dimensional magnets. Chem. Commun. 1997, 0, 1727-1728. [CrossRef]

16. Coronado, E.; Galán-Mascarós, J.R.; Gómez-García, C.J.; Ensling, J.; Gütlich, P. Hybrid Molecular Magnets Obtained by Insertion of Decamethylmetallocenium Cations into Layered, Bimetallic Oxalate Complexes: [ $\left.\mathrm{Z}^{\mathrm{III}} \mathrm{Cp}_{2}{ }_{2}\right]\left[\mathrm{M}^{\mathrm{II}} \mathrm{M}^{\mathrm{III}}(\mathrm{ox})_{3}\right]\left(\mathrm{Z}^{\mathrm{III}}=\mathrm{Co}, \mathrm{Fe} ; \mathrm{M}^{\mathrm{III}}=\mathrm{Cr}, \mathrm{Fe} ; \mathrm{M}^{\mathrm{II}}=\mathrm{Mn}, \mathrm{Fe}, \mathrm{Co}, \mathrm{Cu}, \mathrm{Zn}\right.$; ox=oxalate; $\mathrm{Cp}^{*}=$ pentamethylcyclopentadienyl). Chem. Eur. J. 2000, 6, 552-563. [CrossRef]

17. Coronado, E.; Giménez-Saiz, C.; Gómez-García, C.J.; Romero, F.M.; Tarazón, A. A bottom-up approach from molecular nanographenes to unconventional carbon materials. J. Mater. Chem. 2008, 18, 929-934. [CrossRef]

18. Clemente-León, M.; Coronado, E.; López-Jordà, M.; Waerenborgh, J.C. Multifunctional Magnetic Materials Obtained by Insertion of Spin-Crossover Fe $\mathrm{FIII}^{\mathrm{III}}$ Complexes into Chiral 3D Bimetallic Oxalate-Based Ferromagnets. Inorg. Chem. 2011, 50, 9122-9130. [CrossRef] [PubMed]

19. Clemente-León, M.; Coronado, E.; López-Jordà, M.; Mínguez, E.; Soriano-Portillo, A.; Waerenborgh, J.C. Multifunctional Magnetic Materials Obtained by Insertion of a Spin-Crossover Fe ${ }^{\mathrm{III}}$ Complex into Bimetallic Oxalate-Based Ferromagnets. Chem. Eur. J. 2010, 16, 2207-2219. [CrossRef] [PubMed]

20. Clemente-León, M.; Coronado, E.; López-Jordà, M.; Desplanches, C.; Asthana, S.; Wang, H.; Létard, J.-F. A hybrid magnet with coexistence of ferromagnetism and photoinduced Fe(III) spin-crossover. Chem. Sci. 2011, 2, 1121-1127. [CrossRef]

21. Clemente-León, M.; Coronado, E.; López-Jordà, M. 2D and 3D bimetallic oxalate-based ferromagnets prepared by insertion of different Fe $\mathrm{FII}^{\mathrm{III}}$ spin crossover complexes. Dalton Trans. 2010, 39, 4903-4910. [CrossRef] [PubMed]

22. Bénard, S.; Rivière, E.; Yu, P.; Nakatani, K.; Delouis, J.F. A Photochromic Molecule-Based Magnet. Chem. Mater. 2001, 13, 159-162. [CrossRef]

23. Coronado, E.; Galán-Mascarós, J.R.; Gómez-García, C.J.; Laukhin, V. Coexistence of ferromagnetism and metallic conductivity in a molecule-based layered compound. Nature 2000, 408, 447-449. [CrossRef] [PubMed]

24. Alberola, A.; Coronado, E.; Galán-Mascarós, J.R.; Giménez-Saiz, C.; Gómez-García, C.J. A Molecular Metal Ferromagnet from the Organic Donor Bis(ethylenedithio)tetraselenafulvalene and Bimetallic Oxalate Complexes. J. Am. Chem. Soc. 2003, 125, 10774-10775. [CrossRef] [PubMed]

25. Coronado, E.; Galán-Mascarós, J.R.; Gómez-García, C.J.; Martínez-Ferrero, E.; van Smaalen, S. Incommensurate Nature of the Multilayered Molecular Ferromagnetic Metals Based on Bis(ethylenedithio)tetrathiafulvalene and Bimetallic Oxalate Complexes. Inorg. Chem. 2004, 43, 4808-4810. [CrossRef] [PubMed]

26. Coronado, E.; Galán-Mascarós, J.R. Hybrid molecular conductors. J. Mater. Chem. 2005, 15, 66-74. [CrossRef]

27. Coronado, E.; Curreli, S.; Giménez-Saiz, C.; Gómez-García, C.J. The Series of Molecular Conductors and Superconductors $\mathrm{ET}_{4}\left[\mathrm{AFe}\left(\mathrm{C}_{2} \mathrm{O}_{4}\right)_{3}\right] \cdot \mathrm{PhX}\left(\mathrm{ET}=\right.$ bis(ethylenedithio)tetrathiafulvalene; $\left(\mathrm{C}_{2} \mathrm{O}_{4}\right)^{2-}=$ oxalate; $\mathrm{A}^{+}$ $=\mathrm{H}_{3} \mathrm{O}^{+}, \mathrm{K}^{+} ; \mathrm{X}=\mathrm{F}, \mathrm{Cl}, \mathrm{Br}$, and I): Influence of the Halobenzene Guest Molecules on the Crystal Structure and Superconducting Properties. Inorg. Chem. 2012, 51, 1111-1126. [CrossRef] [PubMed]

28. Ōkawa, H.; Shigematsu, A.; Sadakiyo, M.; Miyagawa, T.; Yoneda, K.; Ohba, M.; Kitagawa, H. Oxalate-Bridged Bimetallic Complexes $\left\{\mathrm{NH}(\mathrm{prol})_{3}\right\}\left[\mathrm{MCr}(\mathrm{ox})_{3}\right]\left(\mathrm{M}=\mathrm{Mn}^{\mathrm{II}}, \mathrm{Fe}^{\mathrm{II}}, \mathrm{Co}^{\mathrm{II}} ; \mathrm{NH}(\mathrm{prol})_{3}{ }^{+}=\right.$ Tri(3-hydroxypropyl)ammonium) Exhibiting Coexistent Ferromagnetism and Proton Conduction. J. Am. Chem. Soc. 2009, 131, 13516-13522. [CrossRef] [PubMed]

29. Pardo, E.; Train, C.; Liu, H.; Chamoreau, L.-M.; Dkhil, B.; Boubekeur, K.; Lloret, F.; Nakatani, K.; Tokoro, H.; Ohkoshi, S.; et al. Multiferroics by Rational Design: Implementing Ferroelectricity in Molecule-Based Magnets. Angew. Chem. Int. Ed. 2012, 51, 8356-8360. [CrossRef] [PubMed]

30. Bénard, S.; Yu, P.; Coradin, T.; Rivière, E.; Nakatani, K.; Clément, R. Design of strongly NLO-active molecularly-based ferromagnets. Adv. Mater. 1997, 9, 981-984. [CrossRef] 
31. Bénard, S.; Yu, P.; Audière, J.P.; Rivière, E.; Clément, R.; Guilhem, J.; Tchertanov, L.; Nakatani, K. Structure and NLO Properties of Layered Bimetallic Oxalato-Bridged Ferromagnetic Networks Containing Stilbazolium-Shaped Chromophores. J. Am. Chem. Soc. 2000, 122, 9444-9454. [CrossRef]

32. Lacroix, P.G.; Malfant, I.; Bénard, S.; Yu, P.; Rivière, E.; Nakatani, K. Hybrid Molecular-Based Magnets Containing Organic NLO Chromophores: A Search toward an Interplay between Magnetic and NLO Behavior. Chem. Mater. 2001, 13, 441-449. [CrossRef]

33. Ōkawa, H.; Mitsumi, M.; Ohba, M.; Kodera, M.; Matsumoto, N. Dithiooxalato(dto)-Bridged Bimetallic Assemblies $\left\{\mathrm{NPr}_{4}\left[\mathrm{MCr}(\mathrm{dto})_{3}\right]\right\}_{\mathrm{x}}\left(\mathrm{M}=\mathrm{Fe}, \mathrm{Co}, \mathrm{Ni}, \mathrm{Zn} ; \mathrm{NPr}_{4}=\right.$ Tetrapropylammonium Ion $)$ : New Complex-Based Ferromagnets. Bull. Chem. Soc. Jpn. 1994, 67, 2139-2144. [CrossRef]

34. Kojima, N.; Aoki, W.; Seto, M.; Kobayashi, Y.; Maeda, Y. Reversible charge-transfer phase transition in $\left[\left(\mathrm{n}-\mathrm{C}_{3} \mathrm{H}_{7}\right)_{4} \mathrm{~N}\right]\left[\mathrm{Fe}^{\mathrm{II}} \mathrm{Fe}^{\mathrm{III}}(\mathrm{dto})_{3}\right]\left(\mathrm{dto}=\mathrm{C}_{2} \mathrm{O}_{2} \mathrm{~S}_{2}\right)$. Synth. Met. 2001, 121, 1796-1797. [CrossRef]

35. Kojima, N.; Aoki, W.; Itoi, M.; Ono, Y.; Seto, M.; Kobayashi, Y.; Maeda, Y. Charge transfer phase transition and ferromagnetism in a mixed-valence iron complex, $\left(\mathrm{n}-\mathrm{C}_{3} \mathrm{H}_{7}\right)_{4} \mathrm{~N}\left[\mathrm{Fe}^{\mathrm{II}} \mathrm{Fe}^{\mathrm{III}}(\mathrm{dto})_{3}\right]\left(\mathrm{dto}=\mathrm{C}_{2} \mathrm{O}_{2} \mathrm{~S}_{2}\right)$. Solid State Commun. 2001, 120, 165-170. [CrossRef]

36. Nakamoto, T.; Miyazaki, Y.; Itoi, M.; Ono, Y.; Kojima, N.; Sorai, M. Heat Capacity of the Mixed-Valence Complex $\left\{\left[\left(\mathrm{n}-\mathrm{C}_{3} \mathrm{H}_{7}\right)_{4} \mathrm{~N}\right]\left[\mathrm{Fe}^{\mathrm{II}} \mathrm{Fe}^{\mathrm{III}}(\mathrm{dto})_{3}\right]\right\}_{\infty}$, Phase Transition because of Electron Transfer, and a Change in Spin-State of the Whole System. Angew. Chem. Int. Ed. 2001, 40, 4716-4719. [CrossRef]

37. Itoi, M.; Taira, A.; Enomoto, M.; Matsushita, N.; Kojima, N.; Kobayashi, Y.; Asai, K.; Koyama, K.; Nakano, T.; Uwatoko, Y. Crystal structure and structural transition caused by charge-transfer phase transition for iron mixed-valence complex $\left(\mathrm{n}-\mathrm{C}_{3} \mathrm{H}_{7}\right)_{4} \mathrm{~N}\left[\mathrm{Fe}^{\mathrm{II}} \mathrm{Fe}^{\mathrm{III}}(\mathrm{dto})_{3}\right]\left(\mathrm{dto}=\mathrm{C}_{2} \mathrm{O}_{2} \mathrm{~S}_{2}\right)$. J. Solid State Commun. 2004, 130, 415-420. [CrossRef]

38. Itoi, M.; Ono, Y.; Kojima, N.; Kato, K.; Osaka, K.; Takata, M. Charge-Transfer Phase Transition and Ferromagnetism of Iron Mixed-Valence Complexes $\left(n-\mathrm{C}_{n} \mathrm{H}_{2 n+1}\right)_{4} \mathrm{~N}\left[\mathrm{Fe}^{\mathrm{II}} \mathrm{Fe}^{\mathrm{III}}(\mathrm{dto})_{3}\right]\left(n=3-6 ; \mathrm{dto}=\mathrm{C}_{2} \mathrm{O}_{2} \mathrm{~S}_{2}\right)$. Eur. J. Inorg. Chem. 2006, 1198-1207. [CrossRef]

39. Kida, N.; Hikita, M.; Kashima, I.; Okubo, M.; Itoi, M.; Enomoto, M.; Kato, K.; Tanaka, M.; Kojima, N. Control of Charge Transfer Phase Transition and Ferromagnetism by Photoisomerization of Spiropyran for an Organic-Inorganic Hybrid System, $(\mathrm{SP})\left[\mathrm{Fe}^{\mathrm{II}} \mathrm{Fe}^{\mathrm{III}}(\mathrm{dto})_{3}\right]\left(\mathrm{SP}=\right.$ spiropyran, dto $\left.=\mathrm{C}_{2} \mathrm{O}_{2} \mathrm{~S}_{2}\right)$. J.Am. Chem. Soc. 2009, 131, 212-220. [CrossRef] [PubMed]

40. Ida, H.; Okazawa, A.; Kojima, N.; Shimizu, R.; Yamada, Y.; Enomoto, M. Effect of Nonmagnetic Substitution on the Magnetic Properties and Charge-Transfer Phase Transition of an Iron Mixed-Valence Complex, $\left(\mathrm{n}-\mathrm{C}_{3} \mathrm{H}_{7}\right)_{4} \mathrm{~N}\left[\mathrm{Fe}^{\mathrm{II}} \mathrm{Fe}^{\mathrm{III}}(\mathrm{dto})_{3}\right.$ ] (dto $\left.=\mathrm{C}_{2} \mathrm{O}_{2} \mathrm{~S}_{2}\right)$. Inorg. Chem. 2012, 51, 8989-8996. [CrossRef] [PubMed]

41. Enomoto, M.; Kojima, N. Magnetic dilution effect on the charge transfer phase transition and the ferromagnetic transition for an iron mixed-valence complex, $\left(\mathrm{n}-\mathrm{C}_{3} \mathrm{H}_{7}\right)_{4} \mathrm{~N}\left[\mathrm{Fe}^{\mathrm{II}}{ }_{1-\mathrm{x}} \mathrm{Zn}_{\mathrm{x}}^{\mathrm{II}} \mathrm{Fe}^{\mathrm{III}}(\mathrm{d} \text { to })_{3}\right](\mathrm{d}$ to $=$ $\mathrm{C}_{2} \mathrm{O}_{2} \mathrm{~S}_{2}$ ). Polyhedron 2009, 28, 1826-1829. [CrossRef]

42. Jones, H.O.; Tasker, H.S. CCXII.-The action of mercaptans on acid chlorides. Part II. The acid chlorides of phosphorus, sulphur, and nitrogen. J. Chem. Soc. 1909, 95, 1910-1918. [CrossRef]

43. Robinson, C.S.; Jones, H.O. VII.-Complex thio-oxalates. J. Chem. Soc. 1912, 101, 62-76. [CrossRef]

44. Dwyer, F.P.; Sargeson, A.M. The Resolution of the Tris-(thio-oxalato) ${ }^{1}$ Complexes of $\mathrm{Co}(\mathrm{III}), \mathrm{Cr}(\mathrm{III})$ and Rh(III). J. Am. Chem. Soc. 1959, 81, 2335-2336. [CrossRef]

45. Irving, H.; Williams, R.J.P. The Stability of Transition-metal Complexes. J. Phys. Chem. 1953, 0, 3192-3210. [CrossRef]

46. Sigel, H.; McCormick, D.B. Discriminating Behavior of Metal Ions and Ligands with Regard to Their Biological Significance. Acc. Chem. Res. 1970, 3, 201-208. [CrossRef]

47. Atovymann, O.L.; Shilov, G.V.; Lyubovskaya, R.N.; Zhilyaeva, E.I.; Ovaneseyan, N.S.; Pirumova, S.I.; Gusakovskaya, I.G.; Morozov, Y.G. Crystal structure of the molecular ferromagnet $\mathrm{NBu}_{4}\left[\mathrm{MnCr}\left(\mathrm{C}_{2} \mathrm{O}_{4}\right)_{3}\right]$ $\left(\mathrm{Bu}=n-\mathrm{C}_{4} \mathrm{H}_{9}\right)$. JETP Lett. 1993, 58, 766-769.

48. Decurtins, S.; Schmale, H.W.; Oswald, H.R.; Linden, A.; Ensling, J.; Giitlich, P.; Hauser, A. A polymeric two-dimensional mixed-metal network. Crystal structure and magnetic properties of $\left\{\left[\mathrm{P}(\mathrm{Ph})_{4}\right]\left[\mathrm{MnCr}(\mathrm{ox})_{3}\right]\right\}$. Inorg. Chim. Acta 1994, 216, 65-73. [CrossRef]

49. Decurtins, S.; Schmalle, H.W.; Pellaux, R.; Schneuwly, P.; Hauser, A. Chiral, Three-Dimensional Supramolecular Compounds: Homo- and Bimetallic Oxalate- and 1,2-Dithiooxalate-Bridged Networks. A Structural and Photophysical Study. Inorg. Chem. 1996, 35, 1451-1460. [CrossRef] [PubMed] 
50. Ovanesyan, N.S.; Shilov, G.V.; Sanina, N.A.; Pyalling, A.A.; Atovmyan, L.O.; Bottyán, L. Structural and Magnetic Properties of Two-Dimensional Oxalate-Bridged Bimetallic Compounds. Mol. Cryst. Liq. Cryst. 1999, 335, 91-104. [CrossRef]

51. Ovanesyan, N.S.; Makhaev, V.D.; Aldoshin, S.M.; Gredin, P.; Boubekeur, K.; Train, C.; Gruselle, M. Structure, magnetism and optical properties of achiral and chiral two-dimensional oxalate-bridged anionic networks with symmetric and symmetric ammonium cations. Dalton Trans. 2005, 0, 3101-3107. [CrossRef] [PubMed]

52. Nuttall, C.J.; Day, P. Modeling Stacking Faults in the Layered Molecular-Based Magnets $\mathrm{AM}^{\mathrm{II}} \mathrm{Fe}\left(\mathrm{C}_{2} \mathrm{O}_{4}\right)_{3}\left\{\mathrm{M}^{\mathrm{II}}\right.$ = Mn, Fe; A = Organic Cation\}. J. Solid State Chem. 1999, 147, 3-10. [CrossRef]

53. Kotani, M. On the Magnetic Moment of Complex Ions. (I). J. Phys. Soc. Jpn. 1949, 4, 293-297. [CrossRef]

54. Kotani, M. Properties of d-Electrons in Complex Salts. Part I: Paramagnetism of Complex Salts. Prog. Theor. Phys. Suppl. 1960, 14, 1-16. [CrossRef]

55. Ono, Y.; Okubo, M.; Kojima, N. Crystal Structure and Ferromagnetism of $\left(\mathrm{n}-\mathrm{C}_{3} \mathrm{H}_{7}\right)_{4} \mathrm{~N}\left[\mathrm{Co}{ }^{\mathrm{II}} \mathrm{Fe}^{\mathrm{III}}(\mathrm{dto})_{3}\right](\mathrm{dto}=$ $\mathrm{C}_{2} \mathrm{O}_{2} \mathrm{~S}_{2}$ ). Solid State Commun. 2003, 126, 291-296. [CrossRef]

56. Mayoh, B.; Day, P. Charge transfer in mixed-valence solids. Part VIII. Contribution of valence delocalisation to the ferromagnetism of Prussian Blue. J. Chem. Soc. Dalton Trans. 1976, 0, 1483-1486. [CrossRef]

57. Carling, S.G.; Bradley, J.M.; Visser, D.; Day, P. Magnetic and structural characterization of the layered materials $\mathrm{AMnFe}\left(\mathrm{C}_{2} \mathrm{~S}_{2} \mathrm{O}_{2}\right)_{3}$. Polyhedron 2003, 22, 2317-2324. [CrossRef]

58. Kida, N.; Enomoto, M.; Watanabe, I.; Suzuki, T.; Kojima, N. Spin dynamics of the charge-transfer phase transition of an iron mixed-valence complex observed using muon spin relaxation spectroscopy. Phys. Rev. B 2008, 77, 144427. [CrossRef]

59. Enomoto, M.; Kida, N.; Watanabe, I.; Suzuki, T.; Kojima, N. Spin dynamics of the ferromagnetic transition in iron mixed-valence complexes, $\left(n-\mathrm{C}_{\mathrm{n}} \mathrm{H}_{2 n+1}\right)_{4} \mathrm{~N}\left[\mathrm{Fe}^{\mathrm{II}} \mathrm{Fe}{ }^{\mathrm{III}}(\mathrm{dto})_{3}\right]\left(\mathrm{dto}=\mathrm{C}_{2} \mathrm{O}_{2} \mathrm{~S}_{2}, \mathrm{n}=3-5\right)$ by $\mu$ SR. Physica $B$ 2009, 404, 642-644. [CrossRef]

(C) 2018 by the authors. Licensee MDPI, Basel, Switzerland. This article is an open access article distributed under the terms and conditions of the Creative Commons Attribution (CC BY) license (http:/ / creativecommons.org/licenses/by/4.0/). 